Review

\title{
Non-Syndromic Intellectual Disability and Its Pathways: A Long Noncoding RNA Perspective
}

\author{
Isabela I. Barros $^{1}$, Vitor Leão ${ }^{1}$, Jessica O. Santis ${ }^{1}$, Reginaldo C. A. Rosa ${ }^{1}$ D, Danielle B. Brotto ${ }^{1}$, Camila B. Storti $^{1}$, \\ Ádamo D. D. Siena ${ }^{1}$, Greice A. Molfetta ${ }^{1}$ and Wilson A. Silva, Jr. ${ }^{1,2,3,4, *(D)}$
}

1 Department of Genetics at the Ribeirão Preto Medical School, University of São Paulo, Avenida Bandeirantes 3900, Monte Alegre, Ribeirão Preto, São Paulo 14049-900, Brazil; isabelaib@usp.br (I.I.B.); leao.vitorleao@alumni.usp.br (V.L.); jessica.santis@usp.br (J.O.S.); reginaldoallves@usp.br (R.C.A.R.); daniellebrotto@alumni.usp.br (D.B.B.); camilabaldin.s@usp.br (C.B.S.); adamo@usp.br (Á.D.D.S.); gamolf@fmrp.usp.br (G.A.M.)

2 National Institute of Science and Technology in Stem Cell and Cell Therapy and Center for Cell Based Therapy, Ribeirão Preto Medical School, University of São Paulo, Rua Tenente Catão Roxo, 2501, Monte Alegre, Ribeirão Preto 14051-140, Brazil

3 Center for Integrative Systems Biology-CISBi, NAP/USP, Ribeirão Preto Medical School, University of São Paulo, Rua Catão Roxo, 2501, Monte Alegre, Ribeirão Preto 14051-140, Brazil

4 Department of Medicine at the Midwest State University of Paraná-UNICENTRO, and Guarapuava Institute for Cancer Research, Rua Fortim Atalaia, 1900, Cidade dos Lagos, Guarapuava 85100-000, Brazil

* Correspondence: wilsonjr@usp.br; Tel.: +55-16-3315-3293

check for updates

Citation: Barros, I.I.; Leão, V.; Santis, J.O.; Rosa, R.C.A.; Brotto, D.B.; Storti, C.B.; Siena, Á.D.D.;

Molfetta, G.A.; Silva, W.A., Jr.

Non-Syndromic Intellectual Disability and Its Pathways: A Long Noncoding RNA Perspective. Non-coding RNA 2021, 7, 22. https://doi.org/10.3390/ ncrna7010022

Received: 12 November 2020 Accepted: 7 December 2020 Published: 11 March 2021

Publisher's Note: MDPI stays neutral with regard to jurisdictional clai$\mathrm{ms}$ in published maps and institutional affiliations.

Copyright: (C) 2021 by the authors. Licensee MDPI, Basel, Switzerland. This article is an open access article distributed under the terms and conditions of the Creative Commons Attribution (CC BY) license (https:// creativecommons.org/licenses/by/ $4.0 /)$.

\begin{abstract}
Non-syndromic intellectual disability (NS-ID or idiopathic) is a complex neurodevelopmental disorder that represents a global health issue. Although many efforts have been made to characterize it and distinguish it from syndromic intellectual disability (S-ID), the highly heterogeneous aspect of this disorder makes it difficult to understand its etiology. Long noncoding RNAs (lncRNAs) comprise a large group of transcripts that can act through various mechanisms and be involved in important neurodevelopmental processes. In this sense, comprehending the roles they play in this intricate context is a valuable way of getting new insights about how NS-ID can arise and develop. In this review, we attempt to bring together knowledge available in the literature about lncRNAs involved with molecular and cellular pathways already described in intellectual disability and neural function, to better understand their relevance in NS-ID and the regulatory complexity of this disorder.
\end{abstract}

Keywords: long noncoding RNA; non-syndromic intellectual disability; molecular and cellular pathways; neurodevelopment; neural function

\section{Intellectual Disability}

Intellectual disability (ID) is characterized by significant intellectual functioning limitation and adaptive behavior occurring before the age of 18 [1]. It is usually defined by an intelligence quotient (IQ) of less than 70 and severe deficiency in the environment and social milieu adaptation [2], which can be caused by genetic, prenatal, and environmental factors, representing a health issue in both developed and developing countries [3].

ID can be classified by severity into five categories (mild, moderate, severe, profound, and unable to classify), and it is also divided into syndromic intellectual disability (S-ID), which includes patients with one or more clinical co-morbidities in addition to ID, and non-syndromic intellectual disability (NS-ID), where ID is the exclusive clinical feature [4]. Distinguishing NS-ID from S-ID is not easy because subtle neurological anomalies and psychiatric disorders are more difficult to diagnose due to the non-specific cognitive impairment [5]. Despite that, many mutations have been identified in genes related to non-syndromic intellectual disability [6-9]. More than 200 candidate genes have been associated with NS-ID, most of which are not shared between NS-ID and S-ID and/or 
neurological and neuropsychiatric diseases [10]. Taken all together, these show the efforts being made to understand the etiology of NS-ID and demonstrate the complexity of trying to define this heterogeneous disorder.

\section{LncRNAs}

Long noncoding RNAs form a large and miscellaneous group of non-protein-coding RNAs, defined as transcripts of more than 200 nucleotides in length. They can regulate gene transcription through a great variety of mechanisms, such as: by the interaction with chromatin-modifying complexes, by binding to other RNA-binding factors which can induce or repress transcription, by acting as enhancers, and by acting as decoys [11]. Because of this wide variety of possible functions, they have been identified and described as acting in countless biological processes, including human embryonic development and neurodevelopment.

In the early stages of human fetal growth, it has been shown that lncRNAs represent the most abundant class of transcripts, both during and after embryonic gene activation [12]. Many of them have also been described as human embryonic stem cells (hESCs) pluripotency regulators, like lncPRESS1, that controls a gene network that controls pluripotency [13], and GAS5, a lncRNA that is directly regulated by pluripotency factors and acts on hESCs self-renewal [14]. Additionally, they have also been described during brain development, a very genetically organized and dynamic process [15], where neural induction takes place. Failures in any step of this process can lead to neurological and cognitive impairments [16], highlighting the importance of a fine and coordinated regulation for healthy brain development. Some lncRNAs have already been associated with neural development, such as PNKY, a transcript involved in the suppression of neuronal commitment of neural stem cells (NSCs) [17], FMR4, a lncRNA that promotes the proliferation of human neural precursor cells (NPCs) [18], and splicing variants of the lncRNA C130071C03Riken, which are involved in neural differentiation [19].

In this context, some lncRNAs have also been directly associated to several neurodevelopmental disorders that have intellectual disability as one of their characteristics, like autism spectrum disorder (ASD) [20-23], Fragile X syndrome [24], Prader-Willi syndrome [25-27], Rett syndrome [28], and Angelman syndrome [29-31]. However, many neurodevelopmental disorders are associated with defective neural differentiation and circuit formation [32], most genes known to cause these diseases belong to a few molecular pathways that are commonly affected [33]. Additionally, little is known about how lncRNAs may be regulating those pathways and how they can be involved in ID. Indeed, scientific articles regarding "IncRNA and intellectual disability" in the PubMed database returns less than 100 articles spanning the last 27 years, and, in a more stringent search, less than 20 articles if the query is specified for "Text word" or "Title/Abstract".

In this review, we sought to explore the roles of IncRNAs in the main pathways involved in NS-ID $[4,34]$, in order to contribute to the elucidation of its complex regulation network.

\section{LncRNAs and Pathways Involved in Non-Syndromic Intellectual Disability and Neural Development}

\subsection{Wnt/ $\beta$-Catenin Pathway}

The Wingless (Wnt) gene family encodes secreted signaling proteins that direct cell proliferation, cell polarity, and cell fate determination during embryonic development and tissue homeostasis [35]. The canonical Wnt signaling pathway (Wnt/ $\beta$-catenin) governs a developmental cascade by regulating the amount of the transcriptional co-regulator $\beta$-catenin within the cell, controlling critical gene expression programs involved in cell proliferation, differentiation, cell adhesion [36], as well as epigenetic/transcriptional regulation [37]. Disbalanced expression of these proteins can disrupt the central nervous system's normal development and cause loss of neurons, fostering neurological disorders [38,39].

Next-generation sequencing enabled better comprehension of multiple dominant mutations in the gene encoding $\beta$-catenin, clarifying its role in cognitive impairment 
and bringing in vivo evidence that deregulation of this pathway leads to intellectual disability $[38,40]$. Despite the lncRNAs inability to code for proteins, it is widely accepted that these molecules can modulate a diverse range of biological processes, including the Wnt/ $\beta$-catenin signaling pathway $[41,42]$.

Notably, the central nervous system expresses a great diversity of lncRNAs, suggesting that their dysregulation plays a critical role in neurological conditions [43,44]. A few lncRNAs have been described to regulate coding genes that are part of the canonical Wnt signaling pathway. For instance, mice experiments showed that downregulation of the Maternally Expressed Gene 3 (MEG3), a lncRNA commonly found overexpressed in neurons of the forebrain of mice [45], modulates the Wnt/ $\beta$-catenin signaling pathway, enhancing nerve growth and alleviating neurological impairment of rats after brain injury [46]. The lncRNA Neat1 was recently reported to enhance the protein levels of core factors of the Wnt/ $\beta$-catenin signaling pathway affecting neuroinflammation damage [47]. Further evidence points out that the signaling axis miR-124-Neat1-Wnt/ $\beta$-catenin plays an essential role in regulating neuronal differentiation, apoptosis, and migration of mouse spinal cord progenitor cells (SC-NPCs) [48]. This study showed that overexpression of miR-124 enhanced the expression of the lncRNA Neat1 and positively regulated mRNAs involved in the Wnt/ $\beta$-catenin pathway. Although the focus is on the therapeutic effectiveness of miR-124/Neat1 for spinal cord injury, clarifying the role of lncRNAs in promoting neuronal differentiation may be relevant to unravel ID pathways [48].

A modulator of the canonical Wnt/ $\beta$-catenin signaling pathway, the SOX family of transcription factors, is widely known for its role in the developing nervous system. For instance, Sox 2 is expressed in neural stem cells regulating self-renewal and differentiation into neurons $[49,50]$. However, Sox genes suffer regulation by lncRNAs, as shown by $\mathrm{Ng}$ et al. that nuclear lncRNA RMST regulates neuronal differentiation and associates with transcription factor SOX2. The author also reported that Sox2 and RMST regulate common targets and RMST downregulation affects SOX2 genome binding [51]. Other lncRNAs that have also been described interfering in SOX regulation include Sox2ot [52] and lincRNARoR [53]. The study of genes that affect neurodevelopment and are associated with diseases that do not start in childhood is also useful to understand intellectual disorders. DISC1 gene, initially described in schizophrenia [54], interacts directly with the GSK3 $\beta$, inhibiting its activity and leading to $\beta$-catenin stabilization. This cascade exerts an influence on neural progenitor proliferation [54]. DISC1 was reported to have the alternative splicing induced by the long non-coding RNA MIAT, leading to its downregulation and disturbing neurodevelopmental mechanisms [55,56].

As shown in this review, much still needs to be unraveled about how long non-coding RNAs regulate genes related to intellectual deficiency. These findings corroborate these molecules' critical role in controlling different components of the Wnt/B-signaling pathway during the earliest stages of neural development.

\subsection{Notch Pathway}

In the developing nervous system, the Notch signaling pathway is involved in repressing neural differentiation-inducing genes, thus preventing NSCs from differentiating and maintaining these embryonic cells $[57,58]$. This pathway is important in regulating the balance between stem cell maintenance and proper neuronal differentiation, so the correct timing is achieved, and the necessary quantity of neurons is produced [59]. It is a highly conserved pathway that, in mammals, contains four receptors (Notch 1-4) and five ligands (D111, D113, D114, Jagged-1, and Jagged-2). Upon ligation of the ligand with the receptor, a proteolytic cleavage occurs, releasing the Notch intracellular domain that translocates to the nucleus and promotes transcription of target genes by interacting with the protein RBPJ [60].

It has already been demonstrated that the ablation of the receptor Notch1 in neuroepithelial cells leads to premature differentiation and apoptosis, failing to generate neural cells [61], which may significantly impact the central nervous system (CNS) development. 
It was also demonstrated that two essential effectors of the Notch signaling are crucial for maintaining the embryonic nervous system structure, keeping the organization and morphology of the cells [62]. Additionally, pathogenic variants of the Notch ligand Dll1 have recently been suggested as causative of a neurodevelopmental phenotype in a cohort whose individuals presented with developmental delay, intellectual disability, and brain malformations [63].

Understanding how lncRNAs may regulate the Notch signaling pathway can bring important highlights about their roles in ID. In 2006, Rani et al. [64] functionally characterized a novel lncRNA, LncND, in a neurodevelopmental disorder related to a microdeletion at 2p25.3, including the LncND locus, and showing ID as one of its phenotypic characteristics. This primate-specific transcript is highly expressed in early neural progenitor cells, and it was demonstrated that it acts as a miRNA sponge. Furthermore, this lncRNA sequesters miR-143-3p and regulates Notch signaling since this miRNA targets NOTCH-1 and NOTCH-2 mRNAs. Through LncND knockdown experiments, the authors showed that cells underwent premature differentiation of neural precursor cells, and through an in vivo overexpression assay, they observed that this lncRNA regulates the expansion of radial glial cells in the murine developing cortex [64].

In an investigation of the transcriptional landscape of embryonic and adult brains, Goff et al. (2015) [65] generated a cohort of 13 lncRNA-null mutant mouse models, which had evidence of expression in neural stem cells and the brain. They observed a more significant number of differentially expressed genes at mouse embryonic day 14.5 (E14.5) compared to adult brains, with significant enrichment of gene sets related to neuronal differentiation and cell fate commitment. In this cohort, one of the mutant strains was a knockout (KO) of KANTR locus. A differential expression analysis between $\mathrm{KO}$ and wild-type (WT) for this strain showed a significant increase in gene sets involved in Notch signaling and neural development in the E14.5 brain. Similarly, the deletion of the lncRNA PERIL locus in the E14.5 brain led to a significant increase in the neural stem cell marker genes Notch 1-3, which was also observed with the ablation of the lncRNA PANTR1 locus [65].

The trisomy 21 found in Down Syndrome (DS) is suggested as associated with delayed neuron formation. Recently, it was shown that the lncRNA XIST, a very well-known transcript in the X-chromosome silencing process, is capable of silencing the extra chromosome 21 (chr21) in DS iPSCs. The silencing of the extra chr21 allows a higher rate of neuron production when compared to the non-silenced cells. Through scRNA-seq analysis, it was revealed that the extra chr21 silencing by XIST significantly dysregulated the Notch signaling pathway and also led to differential expression of TTYH1, an enhancer of this pathway. The elevated expression of Notch signaling genes is then suggested to keep NSCs in the proliferative state, delaying their terminal differentiation into neurons [66].

In summary, these studies highlight how lncRNAs may regulate the Notch signaling pathway and play important roles in neuronal differentiation, which is shown to be strongly related to ID development.

\subsection{Sonic Hedgehog Pathway}

The Sonic hedgehog (Shh) pathway plays a role in the development of tissues and organs, including the CNS, and the determination of tissue polarity. Its role in forming the ventral spinal cord model and early embryonic development has been previously observed [67]. Signaling in this pathway is indispensable for a cell's pattern and fate, especially in the CNS. Throughout vertebrates' CNS development, Shh is required and acts as a morphogenic factor in proliferation, differentiation, and survival of neural precursor cells [68]. In the brain, Shh protein is first expressed ventrally at the early development stages $[69,70]$.

The Shh pathway is classified as canonical when it involves three main components: begins with the Shh ligand binding to Patched (Ptch) protein receptor, which then interacts with and inhibits smoothened (SMO) protein and ends with the regulation of transcriptional 
effectors from the Gli family. Non-canonical Shh occurs when the activation of Ptch/SMO independent of Gli or when the transcriptional factor Gli is activated regardless of the Shh ligand of Ptch/SMO [71]. Shh plays an important role in neurogenesis in the adult mammalian brain, while its receptors, Ptch and Smo, are more expressed in the adult hippocampus and progenitors from this region [72].

Studies of gain and loss of function demonstrated that Shh is essential to induce ventral-neural cell types, and its deficiency affects the establishment of spinal cord structures and brain development. In the brain, altered regulations of the Shh signaling can lead to an extensive range of neurological disorders, brain tumors, and intellectual disability $[73,74]$. Variants in the Shh gene have also been found in patients showing development abnormalities, and speech and learning delays [70,75]. Several non-coding RNAs have been reported as having a role of regulation of the Shh pathway, including lncRNAs, which were shown to function in modulation of neural development and differentiation, with possible effect in the intellectual disability phenotype [76].

The IncRNA AK053922, which is transcribed from the Gli3 locus, is expressed in the early stages of brain development and was shown to have the ability to help specify distinct neuronal cell types by working as a bifunctional transcriptional switch that can either repress or activate Shh signaling [77-79]. Also involved in neurogenesis, lncRNA Gm15577 was identified in the Nbs1-deficient mouse model. Yue et al. [80] demonstrated that Gm15577 regulates the RNA expression of Shh, Nerg1, and $\beta$-catenin, and has important functions in neuronal growth and neuroplasticity [81].

One thoroughly studied lncRNA that regulates brain development is Evf2 (embryonic ventral forebrain 2), which is transcribed antisense to the Dlx6 gene, and therefore also known as Dlx6as1. The locus from which it is transcribed is a homeobox-containing transcription factor, essential for forebrain neurogenesis [82,83]. Evf2 is upregulated during GABAN neurogenesis [79] and is expressed in the telencephalon's Shh-responsive cells during embryonic development [82].

Bond et al. [84] used Evf2 loss-of-function mice to study its role in vivo and reported that Evf2 regulates Dlx6 with mediated concentration-dependent transcriptional control by competition, using both trans and cis mechanisms. The paper also demonstrated that Shh signaling in the embryonic ventral forebrain initiates a transcriptional cascade that requires Evf2 and other lncRNAs for proper GABAergic interneuron development. Other authors also found that Shh activates Efv2 in the embryonic forebrain [85] and is expressed at sonic hedgehog-activated interneuron birth sites in mice [86]. Molecular disturbance of the expression of Evf2 in mice caused a reduction in the number of interneurons in the hippocampus. Even though this decrease was resolved in the mature mice, it was perceived as reducing the inhibition of CA1 pyramidal neuron activity, which suggests a functional defect in these cells $[84,87]$.

\subsection{Growth Factors and Neurotrophic Factors}

Growth factors represent a family of extracellular proteins that induce cell growth and support biological settings [88,89]. Various growth factors have been demonstrated to play a role in the regulation of the adult brain development, in highlighting Fibroblast growth factor-2 (FGF-2), Insulin-like growth factor-1 (IGF-1), and Vascular endothelial growth factor (VEGF). These factors bind to a ligand-specific receptor from the tyrosine kinase family, resulting in the autophosphorylation and activation of its receptors, followed by the activation of signaling pathways, such as PI3K/Akt and MAPK/ERK [90]. Several lncRNAs associated with growth factors have been reported as affecting the brain in conditions of oxygen-glucose deprivation and ischemic stroke, namely MALAT1 [91], Neat1 [92], SNHG12 [93], FENDRR [94], and MEG3 [46].

Neurotrophic factors are signaling proteins playing a role during development, and later, in the adult nervous system. Five neurotrophic factors have been identified in mammals, nerve growth factor (NGF), brain-derived neurotrophic factor (BDNF), Glial cellderived neurotrophic factor (GDNF), neurotrophin 3 (NT-3), and neurotrophin 4/5 (NT- 
4/5). In this pathway, those proteins interact with tyrosine kinases (Trk) receptors and their co-receptor p75NTR [95]. Neurotrophins play an essential role in the moderation of neuronal survival, growth, and differentiation [96], and the lack of these factors may lead to neurodegeneration [97]. Neurotrophins have been associated with several psychiatric disorders, like depression, bipolar disorder, anxiety, and autism spectrum disorders [98-101]. Its upregulation is shown to have beneficial effects on a large range of neurological disorders [102]. BDNF, NGF, and NT-3 have also been considered possible etiologies for attention-deficit/hyperactivity disorder [103].

Brain-derived neurotrophic factor (BDNF) is an important protein for neurodevelopment and maintenance and is one of the most abundant growth factors in the human brain [104]. BDNF plays a role in the coordination of neuronal and glial maturation, participating in axonal, dendritic differentiation, and protecting and enhancing neuronal cell survival [105], and is involved in learning and memory processes [106].

The BDNF locus originates the antisense IncRNA named BDNF-AS, which regulates BDNF mRNA and protein levels in cis [107]. Both transcripts are expressed in several tissues, like the brain, muscle, and embryonic tissues, with the BDNF mRNA having 10to 100-fold higher expression. Inhibition of BDNF-AS caused a 2- to 7-fold increase in BDNF levels, which resulted in elevated neuronal growth, differentiation, survival, and proliferation, both in vitro and in vivo $[108,109]$. However, the magnitude of the increase of BDNF protein was less than the extent of mRNA upregulation [108]. Thus, BDNF-AS is a promising therapeutic target for neurodegenerative and neurodevelopmental disorders in which BDNF is downregulated [110].

Localized in a novel nuclear compartment enriched in pre-mRNA splicing factors [111], lncRNA MIAT, also known as GOMAFU/Gomafu (in humans) and RNCR2, have been shown to play a role in retinal development, postmitotic neuronal function [112], and brain development [79], however, these functions need further explanation. Overexpression of MIAT was associated with reduced apoptosis of neuronal cells through miR-211 and the neurotrophin GDNF, resulting in relief of hypoxic-ischemic injury in mice [113]. MIAT also plays a role as a regulator of neural and vascular cell function via the MIAT/miR150-5p/VEGF network, and its knockdown causes cerebral microvascular degeneration, progressive neuronal loss and neurodegeneration, and behavioral deficits in Alzheimer's disease [114].

MIAT is expressed in a subset of adult mice neurons, including the hippocampus' CA1 region, which suggests the lncRNA role in neuronal excitatory transmission [112]. In two separate studies, MIAT was found upregulated in the nucleus accumbens of cocaine and heroin users, suggesting an effect of the lncRNA in addictive behaviors [45,115]. The dysregulation of MIAT can lead to neurological disorders and has also been implicated in the pathogenesis of schizophrenia, being downregulated upon neuronal activation [116].

Mercer et al. studied lncRNAs expression in neuronal-glial fate specification and oligodendrocyte (OL) lineage maturation and found that MIAT was differentially expressed, being downregulated in neuronal-OL progenitor, while upregulated during neurogenesis and all stages of oligodendrocytes lineage specification and maturation [79]. Using MIAT lncRNA knockout mice, Ip et al. observed that the animals exhibited no gross development defects. However, results from behavioral tests suggested that the animals displayed a mild hyperactivity phenotype accompanied by an increased level of dopamine in comparison with wild-type controls [117].

\subsection{Rho Pathway}

Small GTPases of the Rho family comprise 20 proteins distributed in subfamilies: Cdc42, Rac, Rho, Rnd, RhoD, RhoBTB, and RhoH [118]. These proteins play a key role in numerous neuronal development processes, mainly in neuronal morphology controlling dynamic events of the actin cytoskeleton as well as dendritic and synaptic plasticity. Therefore, it is not surprising that the dysfunction of Rho GTPases is associated with intellectual disability. Also, several ID-related mutations have been found in genes that encode effec- 
tors or regulators of the Rho GTPases: ARHGEF9 (Cdc42 guanine nucleotide exchange factor 9), FGD1 (FYVE, RhoGEF, and PH domain containing 1), OPHN1 (oligophrenin 1), PAK3 (p21 (RAC1)-activated kinase 3), aPIX (Rac/Cdc42 guanine nucleotide exchange factor 6), and TRIO (trio Rho guanine nucleotide exchange factor) $[119,120]$. However, no data were found in the literature corroborating the association between lncRNAs and the RHO pathway in ID.

\subsection{MAPK/ERK Pathway}

The MAPK/ERK pathway, also known as the Ras-Raf-MEK-ERK, acts on the transduction from extracellular information to the intracellular environment, regulating various intracellular functions, including cell proliferation, differentiation, and survival [121-123]. This pathway has been described as acting in the development of the central nervous system, for example, in the embryonic and early postnatal phases, the cascade signals transmitted by MAPK/ERK to progenitor cells inhibit gliogenesis and promote neurogenesis [124]; in neurons, it acts on the dendritic spine stabilization, since it encodes scaffold proteins and adhesion molecules, and participates in the modulation of ionic changes and receptor insertion as well [125].

MAPK/ERK pathway dysfunction has been associated with many neurological pathologies, including ASD [126-128]. It was already reported that transient blockade of the MAPK/ERK pathway on postnatal day 6 in mice caused an increase in apoptosis in the forebrain, and in the long term induced autistic behavioral phenotypes, including social deficits, impaired memory, and reduced long-term potentiation (LTP) in adulthood [129].

N-methyl-D-aspartate receptors (NMDARs) are glutamate-gated ion channels widely expressed in the CNS, regulating neuronal communication and synaptic function [130]. Functional NMDARs are heterotetramers formed by two GluN1 subunits and two glutamate binding GluN2 subunits. The GluN2 subunits can be GluN2A-GluN2D, as well as GluN3A and GluN3B, all of which have distinguishing properties and expression patterns in the CNS [131,132]. Several human genetic studies have reported alterations in NMDARs subunits' genes in a variety of brain diseases, such as intellectual disability, ASD, and epilepsy [133]. Regulation of NMDARs function is a complex process involving numerous proteins in the cell, particularly various protein kinases [134]. The long nucleolus-specific lncRNA (LoNA) has been reported as a regulator of some NMDAR components in mice [135]. LoNA was shown to inhibit rRNA production and ribosome biosynthesis in nucleoli, and eventually, protein synthesis. Additionally, Li et al. showed that levels of synaptic proteins, including NMDA receptor NR1, NR2A, and NR2B, were significantly elevated in the synaptosome fraction isolated from LoNA knockdown mice, ultimately leading to improved neuronal plasticity and long-term potentiation (LTP) [135]. Further studies are required to evaluate whether LoNA may regulate NMDAR components in the context of human neurologic diseases.

SynGAP is a GTPase-activating protein (GAP) selectively expressed in the brain, and that regulates the biochemical signaling in neurons and plays critical roles in neuronal function and brain development $[136,137]$. This protein is a component of the NMDA-receptor complex and acts downstream of the receptor, blocking the AMPA receptor's insertion at the postsynaptic membrane by inhibition of the RAS-ERK pathway [138]. SynGAP is a negative regulator of small GTPases, such as Ras and Rap, and is essential for synaptic development, structure, function, and plasticity Mutations in SYNGAP1, which encodes the SynGAP protein, are a major cause of genetically defined childhood brain disorders, and are found in individuals with ID, ASD, severe epilepsy, and schizophrenia [139,140]. Alongside mutations, non-coding RNAs may play a role in the regulation of SynGAP. An antisense lncRNA to SYNGAP1 (SYNGAP1-AS) was upregulated in the ASD postmortem prefrontal cortex and superior temporal gyrus. These findings raised the idea of regulation by the expression of SYNGAP1 mRNA while affecting epigenetic modification of transcription factors and playing a role in ASD pathology and other neurological diseases related to SynGAP deficiency $[137,141]$. 
The metastasis-associated lung adenocarcinoma transcript 1 (MALAT1), also known as nuclear-enriched transcript 2 (NEAT2), is a lncRNA consisting of more than $8700 \mathrm{nt}$ located on chromosome 11q13 and discovered as a predictive marker for metastasis in early-stage, non-small cell lung cancer [142,143]. MALAT1 is involved in several biological processes, including cell proliferation, migration, and apoptosis [144,145]. Regarding its role in the nervous system and its related pathologies, MALAT1 was expressed in neurons and induced in response to membrane depolarization [146]. In addition, MALAT1 was described as regulating synapse formation by modulating the expression of genes involved in synapse formation or maintenance [147]. MALAT1 has been related to the pathology of several human neurological diseases, including stroke and Alzheimer's disease [148]. Concerning the role of MALAT1 in the regulation of the ERK/MAPK pathway, Chen et al. using in vitro differentiation of neuroblastoma-derived Neuro-2a (N2a) cell as a model for the investigation of lncRNAs in neurogenesis, identified that MALAT1 was one of the most significantly upregulated lncRNAs during N2a cell differentiation. The authors also observed that MALAT1 knockdown resulted in defects in neurite outgrowth as well as enhanced cell death and inhibition of the MAPK/ERK signaling pathway. Therefore, it was found to maintain the survival and synaptic formation of neurocytoma cells by activating the ERK/MAPK signaling pathway [149]. In contrast to the finding reported by Chen et al. [149], a recent study conducted by Shi et al. showed the inhibitory effect of lncRNA-MALAT1 on the MAPK/ERK signaling pathway and its influence on neuronal apoptosis in a rat model of cerebral infarction [150].

In addition to MALAT1, other lncRNAs have been described as interacting molecules with the MAPK/ERK signaling pathway in the nervous system's cells. The long intergenic non-protein-coding RNA p53-induced transcript (LINC-PINT) is a long noncoding RNA induced by $\mathrm{p} 53$ and located on the human chromosome 7 . In mouse cells, LINC-PINT homologous (LincPint) is involved in Polycomb repressive complex 2 (PRC2) and promotes cell proliferation and survival by regulating the expression of genes of the TGF-b, MAPK, and p53 pathways [151]. Additionally, Blüthgen et al. identified that the transcription of LincPint and other IncRNAs is hampered by MEK inhibition in the murine hippocampus, suggesting that this lncRNA could be a candidate for conveying epigenetic changes initiated by MAPK/ERK [152]. Interestingly, in normal human tissues, LINC-PINT expression presents a positive correlation with members of the MAPK pathway and others [151].

The Nuclear Paraspeckle Assembly Transcript 1 (Neat1) is a ubiquitous, highly expressed, nuclear-retained regulatory lncRNA with essential roles in cellular physiology and pathophysiology [153]. This lncRNA can be processed into two isoforms (NEAT1_1 and NEAT1_2), that accumulate in high levels in the nucleus [154,155] and is involved in carcinogenesis [156] and non-cancerous diseases as well, including neurodegeneration and inflammation [157]. In addition to LincPint, Blüthgen et al. also detected that the two alternatively spliced variants of the lncRNA Neat1 were differentially regulated by MAPK/ERK in their murine model, linking this signaling pathway to the regulation of activity-dependent alternative splicing [152].

\subsection{Synaptic Vesicle Trafficking and Exocytosis}

Defects on the regulation of synaptic vesicle fusion and exocytosis may be associated with neurodevelopmental disorders, since this is a tightly controlled process necessary for neurotransmitters' release and neuronal communication [158]. Neurotransmitter signaling may influence early developmental events, such as proliferation, migration, and differentiation, once they serve as chemical signals in the nervous tissue [159]. The binding of neurotransmitters to neuron receptors generates electrical signals that alter the neighboring neuron's morphology and behavior. This process involves gene expression changes that must be maintained for proper maturing neuron development [160].

Alterations that lead to impaired neurotransmission and vesicle trafficking may have a great impact on healthy development. A novel missense mutation identified in the SYN1 gene, for example, was shown to affect synaptic vesicle (SV) clustering at presynaptic 
terminals of neurons and also spontaneous SV release and mobility, causing synaptic function alterations and inducing an X-linked ID phenotype [8]. A further study showed that the most affected $\mathrm{KO}$ mice proteins for the FMR1 gene were associated with signal transduction, neuronal development, and GABA/glutamate neurotransmission. The lack of its encoded protein, FMRP, led to alterations in synaptic vesicles' unloading dynamics, contributing to the aberrant synaptic transmission in Fragile-X syndrome patients [161].

It has been demonstrated that some lncRNAs could affect intellectual development by modulating synaptic vesicle trafficking and exocytosis. Wang et al. analyzed blood samples of ASD children and compared them with controls. Through differential expression analysis, they demonstrated that the lncRNA SNAP25-AS1, which is derived from the SNAP25 locus, is upregulated and associated with the synaptic vesicle cycling pathway [21]. It is known that the synaptosomal-associated protein 25 (SNAP25), together with syntaxin-1A (STX1A) and vesicle-associated membrane protein 2 (VAMP2), mediates neurotransmitters released by the fusion of synaptic vesicles [162,163]. It was also already reported that alterations in gene expression of SNAP25 in mammals are associated with schizophrenia-like behavior [164], and sequence variations in the SNAP25 locus are associated with attention-deficit/hyperactivity disorder (ADHD) [165-167].

It was recently shown that the IncRNA neuroLNC is conserved in mammals and it is tuned by synaptic activity. It was also demonstrated that neuroLNC affects synaptic release due to its interaction with RNA-binding protein TAR DNA binding protein-43 (TDP-43) [168]. This protein colocalizes strongly with endocytic proteins, and it is known to bind several mRNAs that encode synaptic vesicle proteins (e.g., members of syntaxin and synaptotagmin) $[169,170]$. In addition to TDP-43 participating in diverse RNA processes such as synthesis, splicing, stability, and transport [171,172], its importance is highlighted by the inhibition of the endocytosis process, which may be an underlying cause of disrupted neuronal trafficking causing amyotrophic lateral sclerosis (ALS) [170]. In this sense, it was demonstrated by loss-of-function experiments that TDP-43 might impact signaling and endosomal trafficking in neurons [173].

\subsection{Transcriptional Regulation and Chromatin Remodeling}

Long non-coding RNAs promote transcriptional regulation by different mechanisms [11,174]. A typical function of lncRNAs is to modulate the proteins' activity by recruiting chromatin-modifying complexes and specifying histone modifications patterns [175]. A recent report demonstrates that the long non-coding FMR4 plays a role as a chromatin-associated transcript with evidence of functioning as a trans-acting lncRNA in neural precursor cells, regulating distant genomic loci [18]. Evidence pointed out that overexpression of FMR4 significantly altered genome-wide histone methylation status regarding H3K4Me3 and H3K27Me3 marks. The FMR4-mediated histone methylation changes affected the expression of neurodevelopmental genes; besides, the authors suggest that the FMR4 putative targets may be related to its function as a positive regulator of neural precursor cell proliferation [18].

The lincRNA Dali study showed the first evidence of an intergenic long noncoding RNA modulating transcriptional programs of genomically distal regulatory elements [176]. Dali controls the expression of a $50 \mathrm{~kb}$ upstream transcription factor gene, Pou3f3 (also known as BRN1 or Oct8), which plays a role in developing the nervous system [177]. Dali and Pou3f3 share transcriptional targets, regulating gene expression during neural differentiation. Moreover, Dali directly binds to DNA methyltransferase DNMT1, the BRG1 core component of the SWI/SNF family chromatin remodeling BAF complex, the P66beta, and SIN3A transcriptional co-factors, validating its role in chromatin-modifying proteins regulation [176].

A widely known gene to play a role in gene regulation during neurodevelopment is the MeCP2. The encoded protein can bind DNA and regulate gene expression; moreover, MECP2 mutations and dysfunctions have been associated with intellectual disability in several neurodevelopmental disorders [178-180]. The function of MECP2 has been proven 
broader than a mere transcriptional repressor, as initially believed [179]. MeCP2/lncRNAsmediated chromatin remodeling received a closer look. Physical association with the lncRNA RNCR3 (retinal non-coding RNA 3) confers new gene regulation mechanisms by affecting chromatin structure [181].

An alternative mechanism used by lncRNAs to perform transcriptional regulation is by targeting splicing factors. The lncRNA Pnky regulates neuronal differentiation of embryonic and postnatal neural stem cells by binding to the polypyrimidine tract-binding protein 1 (PTBP1), a critical splicing factor during neuronal development $[17,182]$. In NSCs, Pnky binding to PTBP1 regulates neurons' production by controlling key transcripts related to cell differentiation. The lncRNA Tuna, which also binds to PTBP1, has a role in neurogenesis. However, further clarification is needed if their mechanism is by affecting splicing machinery $[183,184]$.

The IncRNA MIAT is involved in a neurogenic commitment by controlling the differentiation of neural progenitors and newborn neurons' survival. In vivo experiments showed that Miat overexpression or RNAi silencing altered the splicing pattern of Wnt7b, promoting changes in variants proportion [185]. The lncRNA CAT7 interacts with the Polycomb Repressive Complex (PRC1) by co-immunoprecipitation. The evidence shows that Cat7 cooperates with the PRC1 to promote gene regulation during neuronal differentiation [186].

With respect to lncRNAs binding directly to chromatin to promote transcriptional regulation, experiments of chromatin isolation by RNA precipitation followed by sequencing (ChIRP-seq) showed that the lnc-Nr2f1 binds to chromatin in an isoform-specific form to distinct genomic loci, regulating neuronal genes in mouse, for instance, the gene Nrp2 involved in neural pathfinding [22].

\section{Concluding Remarks}

LncRNAs have been extensively explored in many biological pathways in recent years and their regulatory importance has been increasingly recognized. Although, their roles in ID are still not deeply understood, leaving a gap in its transcriptional network. This review shows that many lncRNAs are acting in pathways involved in NS-ID (Figure 1). Some transcripts were shown to participate in more than one pathway, reinforcing their versatile mechanisms of action, and some new transcripts were also evidenced. We found a large number of lncRNAs in the transcriptional regulation and chromatin remodeling pathway, followed by Wnt/ $\beta$-catenin, Notch, and MAPK/ERK pathways (Table 1 ), possibly representing the main biological pathways in which lncRNAs act during neurodevelopment. On the other side, the remaining pathways might not have been as explored as the first ones, therefore being potential discovery fields. Another point to be considered is that lncRNAs are relatively new in the RNA research field. Consequently, their impact in ID is still quite limited, which is also due to the large amount of data generated by high-throughput experiments together with their lack of functional characterization. In this sense, we consider this a quite intriguing and fast-growing research area that will be better understood in the future, as the number of researchers in this field increases, and new experimental tools and approaches are developed to explore the diverse roles that lncRNAs play in ID. 


\section{LncRNAs and pathways involved in intellectual disability}

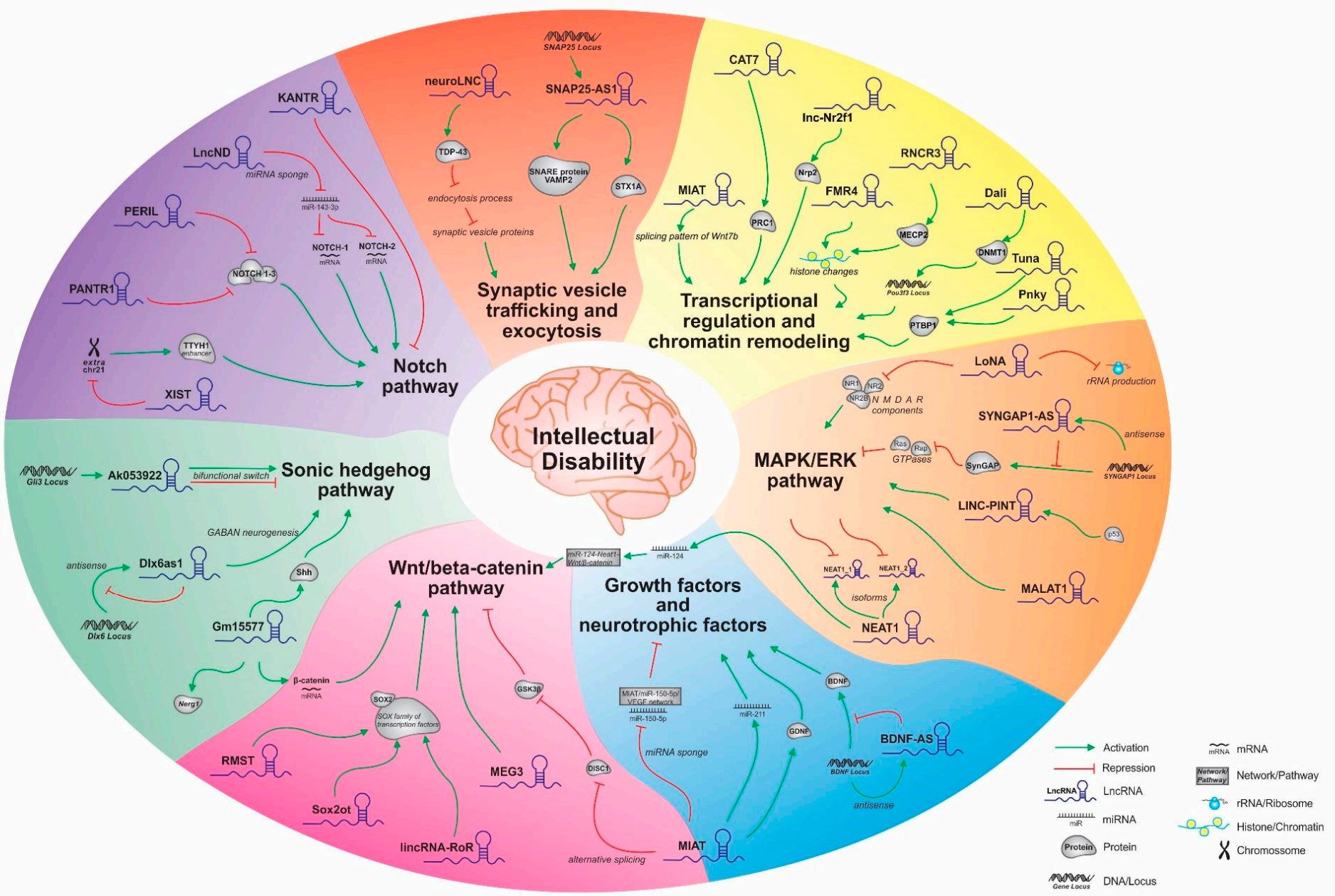

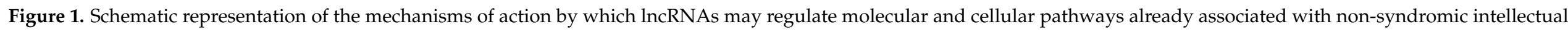
disability and neural function. They play important roles in neurodevelopmental processes, which may have relevant implications for the disease origins and evolution. 
Table 1. Overview of lncRNAs roles in each non-syndromic intellectual disability-related pathway.

\begin{tabular}{|c|c|c|c|c|c|}
\hline Pathway & LncRNA & Ensembl Gene ID & Biotype $^{1}$ & Role in the Pathway & Reference \\
\hline \multirow{6}{*}{ Wnt/ $\beta$-catenin pathway } & MEG3 & ENSG00000214548 & Intergenic & $\begin{array}{l}\text { It modulates the Wnt/ } \beta \text {-catenin signaling pathway, enhancing nerve } \\
\text { growth and alleviating neurological impairment of rats after } \\
\text { brain injury. }\end{array}$ & [46] \\
\hline & Neat1 & ENSG00000245532 & Intergenic & $\begin{array}{l}\text { The signaling axis miR-124-Neat1-Wnt/ } \beta \text {-catenin plays an important } \\
\text { role in regulating neuronal differentiation, apoptosis, and migration of } \\
\text { mouse spinal cord progenitor cells. }\end{array}$ & [48] \\
\hline & RMST & ENSG00000255794 & Intergenic & $\begin{array}{c}\text { Nuclear lncRNA RMST regulates neuronal differentiation and } \\
\text { associates with transcription factor SOX } 2 \text {. }\end{array}$ & [51] \\
\hline & Sox $20 t$ & ENSG00000242808 & Sense overlapping & $\begin{array}{l}\text { Its expression is inversely correlated to Sox } 2 \text { expression during neural } \\
\text { differentiation of mouse ESCs. }\end{array}$ & [52] \\
\hline & $\operatorname{lincRNA-RoR}$ & ENSG00000258609 & Intergenic & $\begin{array}{l}\text { lincRNA-RoR participates in a regulatory loop, together with Sox2, to } \\
\text { help maintain hESC self-renewal balance and may contribute to } \\
\text { genetic networks' regulation during development. }\end{array}$ & [53] \\
\hline & Gomafu & ENSG00000225783 & Intergenic & $\begin{array}{c}\text { The long non-coding RNA Gomafu induces alternative splicing of } \\
\text { DISC1, leading to its downregulation and disturbing } \\
\text { neurodevelopmental mechanisms. }\end{array}$ & {$[45,56]$} \\
\hline \multirow{4}{*}{ Notch } & KANTR & ENSG00000232593 & $\begin{array}{l}\text { Sense overlapping/ } \\
\text { Sense intronic }\end{array}$ & $\begin{array}{l}\text { Knockout mice of KANTR locus increased gene sets involved in Notch } \\
\text { signaling and neural development. }\end{array}$ & [65] \\
\hline & PERIL & NA & NA & $\begin{array}{l}\text { Knockout mice of these lncRNAs locus increased the neural stem cell } \\
\text { marker genes NOTCH1-3. }\end{array}$ & [65] \\
\hline & PANTR1 & ENSG00000233639 & Intergenic & & \\
\hline & XIST & ENSG00000229807 & Intergenic & $\begin{array}{l}\text { XIST silencing of the extra chr21 in Down Syndrome hiPSCs led to } \\
\text { diminished Notch pathway signaling and a higher rate of } \\
\text { neuron production. }\end{array}$ & [66] \\
\hline
\end{tabular}


Table 1. Cont.

\begin{tabular}{|c|c|c|c|c|c|}
\hline Pathway & LncRNA & Ensembl Gene ID & Biotype $^{1}$ & Role in the Pathway & Reference \\
\hline \multirow{3}{*}{ Sonic hedgehog } & AK053922 & NA & NA & $\begin{array}{c}\text { It helps to specify distinct neuronal cell types through acting as a } \\
\text { bifunctional transcriptional switch that can either repress or activate } \\
\text { sonic hedgehog (Shh) signaling. }\end{array}$ & {$[77,78]$} \\
\hline & Gm15577 & ENSMUSG00000086708 & Antisense & $\begin{array}{l}\text { In mice, it modulates } S h h \text { mRNA expression, playing important roles } \\
\text { in neuronal growth and neuroplasticity. }\end{array}$ & [80] \\
\hline & Evf2/DLX6-AS1 & ENSG00000231764 & Antisense & $\begin{array}{l}\text { Evf2 is required for proper GABAergic interneuron development, } \\
\text { through a transcriptional cascade initiated by Shh signaling in the } \\
\text { embryonic ventral forebrain. }\end{array}$ & {$[82,86]$} \\
\hline \multirow{2}{*}{$\begin{array}{l}\text { Growth and } \\
\text { neurotrophic factors }\end{array}$} & $B D N F-A S$ & ENSG00000245573 & Antisense & $\begin{array}{l}\text { Regulates BDNF mRNA and protein levels, which are critical for the } \\
\text { development, survival, and maintenance of neurons in the } \\
\text { nervous system. }\end{array}$ & {$[109,110]$} \\
\hline & MIAT/Gomafu & ENSG00000225783 & Intergenic & $\begin{array}{l}\text { It is involved in brain development and regulation of neural and } \\
\text { vascular cell function via the Gomafu/miR-150-5p/VEGF network. }\end{array}$ & {$[111,112]$} \\
\hline \multirow{4}{*}{ MAPK/ERK } & LoNA & NA & NA & $\begin{array}{c}\text { Knockdown of LoNA led to an increase of NR1, NR2A, and NR2B } \\
\text { proteins in mice and was found in association with improved neuronal } \\
\text { plasticity and long-term potentiation. }\end{array}$ & [135] \\
\hline & MALAT1 & ENSG00000251562 & Intergenic & $\begin{array}{l}\text { Knockdown of MALAT1 resulted in the inhibition of the MAPK/ERK } \\
\text { pathway in mouse N2a cells and also could inhibit this signaling } \\
\text { pathway in a rat model of cerebral infarction. }\end{array}$ & {$[149,150]$} \\
\hline & LINC-PINT & ENSG00000231721 & Intergenic & $\begin{array}{c}\text { In mice, its homologous (LincPint) regulates genes of the MAPK } \\
\text { pathway and its transcription is hampered by MEK inhibition in the } \\
\text { murine hippocampus. In human normal tissues, the expression of } \\
\text { LINC-PINT was positively correlated with the expression of the MAPK } \\
\text { pathway genes. }\end{array}$ & {$[151,152]$} \\
\hline & Neat1 & ENSG00000245532 & Intergenic & $\begin{array}{l}\text { This transcript is processed into two isoforms that are involved in the } \\
\text { pathogenesis of human neurodegenerative diseases and, in mice, its } \\
\text { alternatively spliced variants are differentially regulated by the } \\
\text { MAPK/ERK pathway. }\end{array}$ & [157] \\
\hline
\end{tabular}


Table 1. Cont.

\begin{tabular}{|c|c|c|c|c|c|}
\hline Pathway & LncRNA & Ensembl Gene ID & Biotype $^{1}$ & Role in the Pathway & Reference \\
\hline \multirow{2}{*}{$\begin{array}{l}\text { Synaptic vesicle } \\
\text { trafficking and } \\
\text { exocytosis }\end{array}$} & SNAP25-AS1 & ENSG00000227906 & Antisense & $\begin{array}{l}\text { In ASD patients, it is upregulated and associated with the synaptic } \\
\text { vesicle cycling pathway. }\end{array}$ & [21] \\
\hline & NeuroLNC & NA & NA & $\begin{array}{c}\text { It interacts with TDP-43, affecting synaptic vesicle release, which may } \\
\text { be the cause of disrupted neuro-trafficking in amyotrophic } \\
\text { lateral sclerosis. }\end{array}$ & [168] \\
\hline \multirow{7}{*}{$\begin{array}{l}\text { Transcriptional } \\
\text { regulation and } \\
\text { chromatin remodeling }\end{array}$} & $F M R 4$ & ENSG00000268066 & Antisense & $\begin{array}{l}\text { The FMR4-mediated histone changes affected the expression of } \\
\text { neurodevelopmental genes and its targets may be related to its } \\
\text { function as a positive regulator of neural precursor cell proliferation. }\end{array}$ & [18] \\
\hline & Dali & NA & Intergenic & $\begin{array}{c}\text { Dali controls the expression of the transcription factor gene Pou3f3 } \\
\text { (also known as BRN1 or Oct8), which in turn plays a role in the } \\
\text { development of the nervous system. }\end{array}$ & [177] \\
\hline & RNCR3 & ENSG00000253230 & Intergenic & $\begin{array}{l}\text { Physical association of MECP2 with the lncRNA RNCR3 confers new } \\
\text { mechanisms of gene regulation by affecting chromatin structure. }\end{array}$ & [181] \\
\hline & Pnky & ENSMUSG00000107859 & NA & $\begin{array}{l}\text { It regulates neuronal differentiation of embryonic and postnatal neural } \\
\text { stem cells by binding to the PTBP1 protein. }\end{array}$ & {$[17,182]$} \\
\hline & MIAT & ENSG00000225783 & Intergenic & $\begin{array}{l}\text { It is involved in a neurogenic commitment by controlling the } \\
\text { differentiation of neural progenitors and the survival of } \\
\text { newborn neurons. }\end{array}$ & [185] \\
\hline & CAT7 & NA & NA & $\begin{array}{l}\text { CAT7 cooperates with PRC1 to promote gene regulation during } \\
\text { neuronal differentiation. }\end{array}$ & [186] \\
\hline & $\operatorname{lnc}-N r 2 f 1$ & ENSG00000248588 & Antisense & $\begin{array}{l}\text { lnc-Nr2f1 binds to chromatin in an isoform-specific way to distinct } \\
\text { genomic loci, regulating neuronal genes in mice. }\end{array}$ & [22] \\
\hline
\end{tabular}

${ }^{1}$ Biotypes were obtained with the LNCipedia database (https:/ /lncipedia.org/, accessed on 11 November 2020). NA: Not available. 
Altogether, these evidences emphasize the relevance of lncRNAs in pathways involved in NS-ID, which strongly indicates their relevance in this disorder. Additionally, these studies expand the knowledge about lncRNAs regulatory roles during neurodevelopmental events and demonstrate the highly complex gene networks involved in this process, making it necessary to assess further and validate their NS-ID roles.

Author Contributions: Conceptualization, I.I.B. and W.A.S.J.; literature investigation, I.I.B., J.O.S., R.C.A.R., D.B.B., C.B.S. and Á.D.D.S.; writing-original draft preparation, I.I.B., J.O.S., R.C.A.R., D.B.B., C.B.S. and Á.D.D.S.; figure-conceptualization, I.I.B., V.L., J.O.S. and R.C.A.R.; figure-original draft and editing, V.L.; table-conceptualization, I.I.B., R.C.A.R.; table—writing, editing and review, I.I.B., J.O.S., R.C.A.R., D.B.B. and C.B.S.; writing-critical review, G.A.M. and W.A.S.J.; writingediting, I.I.B., J.O.S., R.C.A.R., D.B.B., C.B.S. and G.A.M.; text formatting, V.L. and J.O.S.; supervision, I.I.B. and W.A.S.J. All authors have read and agreed to the published version of the manuscript.

Funding: The authors disclose receipt of the following financial support for the research, authorship, and/or publication of this article: This work was jointly supported by The Coordination of Superior Level Staff Improvement (CAPES), the National Council for Scientific and Technological Development (CNPq), grant no. 465539/2014-9; São Paulo Research Foundation (FAPESP), grant nos. 2009/53853-5 and 2013/08135-2.

Conflicts of Interest: The authors declare no conflict of interest.

\section{References}

1. AAIDD. American Association on Intellectual Developmental Disabilities. Intellectual Disability: Definition, Classification, and Systems of Supports; AAIDD: Washington, DC, USA, 2010.

2. Iwase, S.; Berube, N.G.; Zhou, Z.; Kasri, N.N.; Battaglioli, E.; Scandaglia, M.; Barco, A. Epigenetic Etiology of Intellectual Disability. J. Neurosci. 2017, 37, 10773-10782. [CrossRef] [PubMed]

3. Linn, J.G.; Chuaqui, J.; Wilson, D.R.; Arredondo, E. The Global Impact of Intellectual Disability and Other Mental Disorders in Children. Int. J. Childbirth Educ. 2019, 34, 14-17.

4. Kaufman, L.; Ayub, M.; Vincent, J.B. The genetic basis of non-syndromic intellectual disability: A review. J. Neurodev. Disord. 2010, 2, 182-209. [CrossRef] [PubMed]

5. Valnegri, P.; Sala, C.; Passafaro, M. Synaptic dysfunction and intellectual disability. Adv. Exp. Med. Biol. 2012, 970, 433-449. [CrossRef] [PubMed]

6. Muthusamy, B.; Bellad, A.; Prasad, P.; Bandari, A.K.; Bhuvanalakshmi, G.; Kiragasur, R.M.; Girimaj, S.C.; Pandey, A. A Novel LINS1 Truncating Mutation in Autosomal Recessive Nonsyndromic Intellectual Disability. Front. Psychiatry 2020, $11,354$. [CrossRef] [PubMed]

7. Wu, Y.; Zhang, H.; Liu, X.; Shi, Z.; Li, H.; Wang, Z.; Jie, X.; Huang, S.; Zhang, F.; Li, J.; et al. Mutations of ARX and non-syndromic intellectual disability in Chinese population. Genes Genom. 2019, 41, 125-131. [CrossRef]

8. Guarnieri, F.C.; Pozzi, D.; Raimondi, A.; Fesce, R.; Valente, M.M.; Delvecchio, V.S.; Van Esch, H.; Matteoli, M.; Benfenati, F.; D'Adamo, P.; et al. A novel SYN1 missense mutation in non-syndromic X-linked intellectual disability affects synaptic vesicle life cycle, clustering and mobility. Hum. Mol. Genet. 2017, 26, 4699-4714. [CrossRef]

9. Rauch, A.; Wieczorek, D.; Graf, E.; Wieland, T.; Endele, S.; Schwarzmayr, T.; Albrecht, B.; Bartholdi, D.; Beygo, J.; Di Donato, N.; et al. Range of genetic mutations associated with severe non-syndromic sporadic intellectual disability: An exome sequencing study. Lancet 2012, 380, 1674-1682. [CrossRef]

10. Lee, S.; Rudd, S.; Gratten, J.; Visscher, P.M.; Prins, J.B.; Dawson, P.A. Gene networks associated with non-syndromic intellectual disability. J. Neurogenet. 2018, 32, 6-14. [CrossRef]

11. Bhat, S.A.; Ahmad, S.M.; Mumtaz, P.T.; Malik, A.A.; Dar, M.A.; Urwat, U.; Shah, R.A.; Ganai, N.A. Long non-coding RNAs: Mechanism of action and functional utility. Non Coding RNA Res. 2016, 1, 43-50. [CrossRef]

12. Bouckenheimer, J.; Assou, S.; Riquier, S.; Hou, C.; Philippe, N.; Sansac, C.; Lavabre-Bertrand, T.; Commes, T.; Lemaitre, J.M.; Boureux, A.; et al. Long non-coding RNAs in human early embryonic development and their potential in ART. Hum. Reprod. Update 2016, 23, 19-40. [CrossRef] [PubMed]

13. Jain, A.K.; Xi, Y.; McCarthy, R.; Allton, K.; Akdemir, K.C.; Patel, L.R.; Aronow, B.; Lin, C.; Li, W.; Yang, L.; et al. LncPRESS1 Is a p53-Regulated LncRNA that Safeguards Pluripotency by Disrupting SIRT6-Mediated De-acetylation of Histone H3K56. Mol. Cell 2016, 64, 967-981. [CrossRef] [PubMed]

14. Xu, C.; Zhang, Y.; Wang, Q.; Xu, Z.; Jiang, J.; Gao, Y.; Gao, M.; Kang, J.; Wu, M.; Xiong, J.; et al. Long non-coding RNA GAS5 controls human embryonic stem cell self-renewal by maintaining NODAL signalling. Nat. Commun. 2016, 7, 13287. [CrossRef] [PubMed]

15. Stiles, J.; Jernigan, T.L. The basics of brain development. Neuropsychol. Rev. 2010, 20, 327-348. [CrossRef] [PubMed] 
16. Li, G.; Jiapaer, Z.; Weng, R.; Hui, Y.; Jia, W.; Xi, J.; Wang, G.; Zhu, S.; Zhang, X.; Feng, D.; et al. Dysregulation of the SIRT1/OCT6 Axis Contributes to Environmental Stress-Induced Neural Induction Defects. Stem Cell Rep. 2017, 8, 1270-1286. [CrossRef] [PubMed]

17. Ramos, A.D.; Andersen, R.E.; Liu, S.J.; Nowakowski, T.J.; Hong, S.J.; Gertz, C.; Salinas, R.D.; Zarabi, H.; Kriegstein, A.R.; Lim, D.A. The long noncoding RNA Pnky regulates neuronal differentiation of embryonic and postnatal neural stem cells. Cell Stem Cell 2015, 16, 439-447. [CrossRef]

18. Peschansky, V.J.; Pastori, C.; Zeier, Z.; Wentzel, K.; Velmeshev, D.; Magistri, M.; Silva, J.P.; Wahlestedt, C. The long non-coding RNA FMR4 promotes proliferation of human neural precursor cells and epigenetic regulation of gene expression in trans. Mol. Cell. Neurosci. 2016, 74, 49-57. [CrossRef]

19. Zhang, L.; Xue, Z.; Yan, J.; Wang, J.; Liu, Q.; Jiang, H. LncRNA Riken-201 and Riken-203 modulates neural development by regulating the Sox6 through sequestering miRNAs. Cell Prolif. 2019, 52, e12573. [CrossRef]

20. Ziats, M.N.; Rennert, O.M. Aberrant expression of long noncoding RNAs in autistic brain. J. Mol. Neurosci. 2013, 49, 589-593. [CrossRef]

21. Wang, Y.; Zhao, X.; Ju, W.; Flory, M.; Zhong, J.; Jiang, S.; Wang, P.; Dong, X.; Tao, X.; Chen, Q.; et al. Genome-wide differential expression of synaptic long noncoding RNAs in autism spectrum disorder. Transl. Psychiatry 2015, 5, e660. [CrossRef]

22. Ang, C.E.; Ma, Q.; Wapinski, O.L.; Fan, S.; Flynn, R.A.; Lee, Q.Y.; Coe, B.; Onoguchi, M.; Olmos, V.H.; Do, B.T.; et al. The novel lncRNA lnc-NR2F1 is pro-neurogenic and mutated in human neurodevelopmental disorders. eLife 2019, 8, 41770. [CrossRef]

23. Alinejad-Rokny, H.; Heng, J.I.T.; Forrest, A.R.R. Brain-Enriched Coding and Long Non-coding RNA Genes Are Overrepresented in Recurrent Neurodevelopmental Disorder CNVs. Cell Rep. 2020, 33, 108307. [CrossRef] [PubMed]

24. Pastori, C.; Peschansky, V.J.; Barbouth, D.; Mehta, A.; Silva, J.P.; Wahlestedt, C. Comprehensive analysis of the transcriptional landscape of the human FMR1 gene reveals two new long noncoding RNAs differentially expressed in Fragile X syndrome and Fragile X-associated tremor/ataxia syndrome. Hum. Genet. 2014, 133, 59-67. [CrossRef] [PubMed]

25. Buiting, K.; Nazlican, H.; Galetzka, D.; Wawrzik, M.; Gross, S.; Horsthemke, B. C15orf2 and a novel noncoding transcript from the Prader-Willi/Angelman syndrome region show monoallelic expression in fetal brain. Genomics 2007, 89, 588-595. [CrossRef] [PubMed]

26. Wu, H.; Yin, Q.F.; Luo, Z.; Yao, R.W.; Zheng, C.C.; Zhang, J.; Xiang, J.F.; Yang, L.; Chen, L.L. Unusual Processing Generates SPA LncRNAs that Sequester Multiple RNA Binding Proteins. Mol. Cell 2016, 64, 534-548. [CrossRef] [PubMed]

27. Chung, M.S.; Langouet, M.; Chamberlain, S.J.; Carmichael, G.G. Prader-Willi syndrome: Reflections on seminal studies and future therapies. Open Biol. 2020, 10, 200195. [CrossRef] [PubMed]

28. Petazzi, P.; Sandoval, J.; Szczesna, K.; Jorge, O.C.; Roa, L.; Sayols, S.; Gomez, A.; Huertas, D.; Esteller, M. Dysregulation of the long non-coding RNA transcriptome in a Rett syndrome mouse model. RNA Biol. 2013, 10, 1197-1203. [CrossRef]

29. Meng, L.; Ward, A.J.; Chun, S.; Bennett, C.F.; Beaudet, A.L.; Rigo, F. Towards a therapy for Angelman syndrome by targeting a long non-coding RNA. Nature 2015, 518, 409-412. [CrossRef]

30. Wolter, J.M.; Mao, H.; Fragola, G.; Simon, J.M.; Krantz, J.L.; Bazick, H.O.; Oztemiz, B.; Stein, J.L.; Zylka, M.J. Cas9 gene therapy for Angelman syndrome traps Ube3a-ATS long non-coding RNA. Nature 2020, 587, 281-284. [CrossRef]

31. Plagge, A. Non-Coding RNAs at the Gnas and Snrpn-Ube3a Imprinted Gene Loci and Their Involvement in Hereditary Disorders. Front. Genet. 2012, 3, 264. [CrossRef]

32. Hsueh, Y.P. Synaptic Formation, Neural Circuits and Neurodevelopmental Disorders Controlled by Signaling, Translation, and Epigenetic Regulation. Dev. Neurobiol. 2019, 79, 2-7. [CrossRef] [PubMed]

33. Parenti, I.; Rabaneda, L.G.; Schoen, H.; Novarino, G. Neurodevelopmental Disorders: From Genetics to Functional Pathways. Trends Neurosci. 2020, 43, 608-621. [CrossRef] [PubMed]

34. Faigle, R.; Song, H. Signaling mechanisms regulating adult neural stem cells and neurogenesis. Biochim. Biophys. Acta 2013, 1830, 2435-2448. [CrossRef] [PubMed]

35. Clevers, H.; Nusse, R. Wnt/beta-catenin signaling and disease. Cell 2012, 149, 1192-1205. [CrossRef]

36. MacDonald, B.T.; Tamai, K.; He, X. Wnt/beta-catenin signaling: Components, mechanisms, and diseases. Dev. Cell 2009, 17, 9-26. [CrossRef]

37. Katoh, M. Mutation spectra of histone methyltransferases with canonical SET domains and EZH2-targeted therapy. Epigenomics 2016, 8, 285-305. [CrossRef]

38. Tucci, V.; Kleefstra, T.; Hardy, A.; Heise, I.; Maggi, S.; Willemsen, M.H.; Hilton, H.; Esapa, C.; Simon, M.; Buenavista, M.T.; et al. Dominant beta-catenin mutations cause intellectual disability with recognizable syndromic features. J. Clin. Investig. 2014, 124, 1468-1482. [CrossRef]

39. Dubruc, E.; Putoux, A.; Labalme, A.; Rougeot, C.; Sanlaville, D.; Edery, P. A new intellectual disability syndrome caused by CTNNB1 haploinsufficiency. Am. J. Med. Genet. Part A 2014, 164, 1571-1575. [CrossRef]

40. Harripaul, R.; Noor, A.; Ayub, M.; Vincent, J.B. The Use of Next-Generation Sequencing for Research and Diagnostics for Intellectual Disability. Cold Spring Harb. Perspect. Med. 2017, 7, a026864. [CrossRef]

41. Fancy, S.P.; Harrington, E.P.; Baranzini, S.E.; Silbereis, J.C.; Shiow, L.R.; Yuen, T.J.; Huang, E.J.; Lomvardas, S.; Rowitch, D.H. Parallel states of pathological Wnt signaling in neonatal brain injury and colon cancer. Nat. Neurosci. 2014, 17, 506-512. [CrossRef]

42. Salmaso, N.; Jablonska, B.; Scafidi, J.; Vaccarino, F.M.; Gallo, V. Neurobiology of premature brain injury. Nat. Neurosci. 2014, 17, 341-346. [CrossRef] 
43. Talkowski, M.E.; Maussion, G.; Crapper, L.; Rosenfeld, J.A.; Blumenthal, I.; Hanscom, C.; Chiang, C.; Lindgren, A.; Pereira, S.; Ruderfer, D.; et al. Disruption of a large intergenic noncoding RNA in subjects with neurodevelopmental disabilities. Am. $J$. Hum. Genet. 2012, 91, 1128-1134. [CrossRef]

44. Chen, R.; Liu, L.; Xiao, M.; Wang, F.; Lin, X. Microarray expression profile analysis of long noncoding RNAs in premature brain injury: A novel point of view. Neuroscience 2016, 319, 123-133. [CrossRef]

45. Michelhaugh, S.K.; Lipovich, L.; Blythe, J.; Jia, H.; Kapatos, G.; Bannon, M.J. Mining Affymetrix microarray data for long non-coding RNAs: Altered expression in the nucleus accumbens of heroin abusers. J. Neurochem. 2011, 116, 459-466. [CrossRef] [PubMed]

46. You, D.; You, H. Repression of long non-coding RNA MEG3 restores nerve growth and alleviates neurological impairment after cerebral ischemia-reperfusion injury in a rat model. Biomed. Pharmacother. 2019, 111, 1447-1457. [CrossRef] [PubMed]

47. Han, D.; Zhou, Y. YY1-induced upregulation of lncRNA NEAT1 contributes to OGD/R injury-induced inflammatory response in cerebral microglial cells via Wnt/beta-catenin signaling pathway. Vitr. Cell. Dev. Biol. Anim. 2019, 55, 501-511. [CrossRef] [PubMed]

48. Cui, Y.; Yin, Y.; Xiao, Z.; Zhao, Y.; Chen, B.; Yang, B.; Xu, B.; Song, H.; Zou, Y.; Ma, X.; et al. LncRNA Neat1 mediates miR124-induced activation of Wnt/beta-catenin signaling in spinal cord neural progenitor cells. Stem Cell Res. Ther. 2019, 10, 400. [CrossRef]

49. Mercurio, S.; Serra, L.; Nicolis, S.K. More than just Stem Cells: Functional Roles of the Transcription Factor Sox2 in Differentiated Glia and Neurons. Int. J. Mol. Sci. 2019, 20, 4540. [CrossRef]

50. Kormish, J.D.; Sinner, D.; Zorn, A.M. Interactions between SOX factors and Wnt/beta-catenin signaling in development and disease. Dev. Dyn. 2010, 239, 56-68. [CrossRef]

51. Ng, S.Y.; Bogu, G.K.; Soh, B.S.; Stanton, L.W. The long noncoding RNA RMST interacts with SOX2 to regulate neurogenesis. Mol. Cell 2013, 51, 349-359. [CrossRef]

52. Messemaker, T.C.; van Leeuwen, S.M.; van den Berg, P.R.; t Jong, A.E.J.; Palstra, R.J.; Hoeben, R.C.; Semrau, S.; Mikkers, H.M.M. Allele-specific repression of Sox2 through the long non-coding RNA Sox2ot. Sci. Rep. 2018, 8, 386. [CrossRef] [PubMed]

53. Wang, Y.; Xu, Z.; Jiang, J.; Xu, C.; Kang, J.; Xiao, L.; Wu, M.; Xiong, J.; Guo, X.; Liu, H. Endogenous miRNA sponge lincRNA-RoR regulates Oct4, Nanog, and Sox2 in human embryonic stem cell self-renewal. Dev. Cell 2013, 25, 69-80. [CrossRef] [PubMed]

54. Mao, Y.; Ge, X.; Frank, C.L.; Madison, J.M.; Koehler, A.N.; Doud, M.K.; Tassa, C.; Berry, E.M.; Soda, T.; Singh, K.K.; et al. Disrupted in schizophrenia 1 regulates neuronal progenitor proliferation via modulation of GSK3beta/beta-catenin signaling. Cell 2009, 136, 1017-1031. [CrossRef] [PubMed]

55. Jaaro-Peled, H.; Hayashi-Takagi, A.; Seshadri, S.; Kamiya, A.; Brandon, N.J.; Sawa, A. Neurodevelopmental mechanisms of schizophrenia: Understanding disturbed postnatal brain maturation through neuregulin-1-ErbB4 and DISC1. Trends Neurosci. 2009, 32, 485-495. [CrossRef]

56. Morikawa, T.; Manabe, T. Aberrant regulation of alternative pre-mRNA splicing in schizophrenia. Neurochem. Int. 2010, 57, 691-704. [CrossRef]

57. Imayoshi, I.; Kageyama, R. The role of Notch signaling in adult neurogenesis. Mol. Neurobiol. 2011, 44, 7-12. [CrossRef]

58. Zhang, R.; Engler, A.; Taylor, V. Notch: An interactive player in neurogenesis and disease. Cell Tissue Res. 2018, 371, 73-89. [CrossRef]

59. Imayoshi, I.; Shimojo, H.; Sakamoto, M.; Ohtsuka, T.; Kageyama, R. Genetic visualization of notch signaling in mammalian neurogenesis. Cell. Mol. Life Sci. 2013, 70, 2045-2057. [CrossRef]

60. Reicher, A.; Fosselteder, J.; Kwong, L.N.; Pichler, M. Crosstalk between the Notch signaling pathway and long non-coding RNAs. Cancer Lett. 2018, 420, 91-96. [CrossRef]

61. Lutolf, S.; Radtke, F.; Aguet, M.; Suter, U.; Taylor, V. Notch1 is required for neuronal and glial differentiation in the cerebellum. Development 2002, 129, 373-385.

62. Hatakeyama, J.; Bessho, Y.; Katoh, K.; Ookawara, S.; Fujioka, M.; Guillemot, F.; Kageyama, R. Hes genes regulate size, shape and histogenesis of the nervous system by control of the timing of neural stem cell differentiation. Development 2004, 131, 5539-5550. [CrossRef]

63. Fischer-Zirnsak, B.; Segebrecht, L.; Schubach, M.; Charles, P.; Alderman, E.; Brown, K.; Cadieux-Dion, M.; Cartwright, T.; Chen, Y.; Costin, C.; et al. Haploinsufficiency of the Notch Ligand DLL1 Causes Variable Neurodevelopmental Disorders. Am. J. Hum. Genet. 2019, 105, 631-639. [CrossRef] [PubMed]

64. Rani, N.; Nowakowski, T.J.; Zhou, H.; Godshalk, S.E.; Lisi, V.; Kriegstein, A.R.; Kosik, K.S. A Primate lncRNA Mediates Notch Signaling during Neuronal Development by Sequestering miRNA. Neuron 2016, 90, 1174-1188. [CrossRef] [PubMed]

65. Goff, L.A.; Groff, A.F.; Sauvageau, M.; Trayes-Gibson, Z.; Sanchez-Gomez, D.B.; Morse, M.; Martin, R.D.; Elcavage, L.E.; Liapis, S.C.; Gonzalez-Celeiro, M.; et al. Spatiotemporal expression and transcriptional perturbations by long noncoding RNAs in the mouse brain. Proc. Natl. Acad. Sci. USA 2015, 112, 6855-6862. [CrossRef] [PubMed]

66. Czerminski, J.T.; Lawrence, J.B. Silencing Trisomy 21 with XIST in Neural Stem Cells Promotes Neuronal Differentiation. Dev. Cell 2020, 52, 294-308 e293. [CrossRef]

67. Abramyan, J. Hedgehog Signaling and Embryonic Craniofacial Disorders. J. Dev. Biol. 2019, 7, 9. [CrossRef]

68. Yang, C.; Li, X.; Liu, Y.; Li, H.; Guo, Z.; Lin, J. Sonic hedgehog overexpression regulates the neuroepithelial cells proliferation in the spinal cord of dorsal regions during chicken embryo development. Neuro Endocrinol. Lett. 2015, 36, 380-386. 
69. Ruiz i Altaba, A.; Palma, V.; Dahmane, N. Hedgehog-Gli signalling and the growth of the brain. Nat. Rev. Neurosci. $2002,3,24-33$. [CrossRef]

70. Li, X.; Li, Y.; Li, S.; Li, H.; Yang, C.; Lin, J. The role of Shh signalling pathway in central nervous system development and related diseases. Cell Biochem. Funct. 2020. [CrossRef]

71. Rimkus, T.K.; Carpenter, R.L.; Qasem, S.; Chan, M.; Lo, H.W. Targeting the Sonic Hedgehog Signaling Pathway: Review of Smoothened and GLI Inhibitors. Cancers 2016, 8, 22. [CrossRef]

72. Lai, K.; Kaspar, B.K.; Gage, F.H.; Schaffer, D.V. Sonic hedgehog regulates adult neural progenitor proliferation in vitro and in vivo. Nat. Neurosci. 2003, 6, 21-27. [CrossRef] [PubMed]

73. Marti, E.; Bumcrot, D.A.; Takada, R.; McMahon, A.P. Requirement of 19K form of Sonic hedgehog for induction of distinct ventral cell types in CNS explants. Nature 1995, 375, 322-325. [CrossRef] [PubMed]

74. Patel, S.S.; Tomar, S.; Sharma, D.; Mahindroo, N.; Udayabanu, M. Targeting sonic hedgehog signaling in neurological disorders. Neurosci. Biobehav. Rev. 2017, 74, 76-97. [CrossRef] [PubMed]

75. Hehr, U.; Gross, C.; Diebold, U.; Wahl, D.; Beudt, U.; Heidemann, P.; Hehr, A.; Mueller, D. Wide phenotypic variability in families with holoprosencephaly and a sonic hedgehog mutation. Eur. J. Pediatr. 2004, 163, 347-352. [CrossRef] [PubMed]

76. Wu, P.; Zuo, X.; Deng, H.; Liu, X.; Liu, L.; Ji, A. Roles of long noncoding RNAs in brain development, functional diversification and neurodegenerative diseases. Brain Res. Bull. 2013, 97, 69-80. [CrossRef]

77. Hashimoto-Torii, K.; Motoyama, J.; Hui, C.C.; Kuroiwa, A.; Nakafuku, M.; Shimamura, K. Differential activities of Sonic hedgehog mediated by Gli transcription factors define distinct neuronal subtypes in the dorsal thalamus. Mech. Dev. 2003, 120, 1097-1111. [CrossRef]

78. Meyer, N.P.; Roelink, H. The amino-terminal region of Gli3 antagonizes the Shh response and acts in dorsoventral fate specification in the developing spinal cord. Dev. Biol. 2003, 257, 343-355. [CrossRef]

79. Mercer, T.R.; Qureshi, I.A.; Gokhan, S.; Dinger, M.E.; Li, G.; Mattick, J.S.; Mehler, M.F. Long noncoding RNAs in neuronal-glial fate specification and oligodendrocyte lineage maturation. BMC Neurosci. 2010, 11, 14. [CrossRef]

80. Yue, Y.; Zhang, W.; Liu, C.; Niu, Y.; Tong, W. Long non-coding RNA Gm15577 is involved in mouse cerebellar neurogenesis. Zhonghua Bing Li Xue Za Zhi Chin. J. Pathol. 2015, 44, 504-508.

81. Zhong, W.; Huang, Q.; Zeng, L.; Hu, Z.; Tang, X. Caveolin-1 and MLRs: A potential target for neuronal growth and neuroplasticity after ischemic stroke. Int. J. Med. Sci. 2019, 16, 1492-1503. [CrossRef]

82. Feng, J.; Bi, C.; Clark, B.S.; Mady, R.; Shah, P.; Kohtz, J.D. The Evf-2 noncoding RNA is transcribed from the Dlx-5/6 ultraconserved region and functions as a Dlx-2 transcriptional coactivator. Genes Dev. 2006, 20, 1470-1484. [CrossRef] [PubMed]

83. Van de, V., II; Gordebeke, P.M.; Khoshab, N.; Tiesinga, P.H.; Buitelaar, J.K.; Kozicz, T.; Aschrafi, A.; Glennon, J.C. Long non-coding RNAs in neurodevelopmental disorders. Front. Mol. Neurosci. 2013, 6, 53. [CrossRef]

84. Bond, A.M.; Vangompel, M.J.; Sametsky, E.A.; Clark, M.F.; Savage, J.C.; Disterhoft, J.F.; Kohtz, J.D. Balanced gene regulation by an embryonic brain ncRNA is critical for adult hippocampal GABA circuitry. Nat. Neurosci. 2009, 12, 1020-1027. [CrossRef] [PubMed]

85. Kohtz, J.D.; Baker, D.P.; Corte, G.; Fishell, G. Regionalization within the mammalian telencephalon is mediated by changes in responsiveness to Sonic Hedgehog. Development 1998, 125, 5079-5089.

86. Cajigas, I.; Chakraborty, A.; Swyter, K.R.; Luo, H.; Bastidas, M.; Nigro, M.; Morris, E.R.; Chen, S.; VanGompel, M.J.W.; Leib, D.; et al. The Evf2 Ultraconserved Enhancer lncRNA Functionally and Spatially Organizes Megabase Distant Genes in the Developing Forebrain. Mol. Cell 2018, 71, 956-972.e9. [CrossRef]

87. Clark, B.S.; Blackshaw, S. Understanding the Role of lncRNAs in Nervous System Development. Adv. Exp. Med. Biol. 2017, 1008, 253-282. [CrossRef]

88. Guillemot, F.; Zimmer, C. From cradle to grave: The multiple roles of fibroblast growth factors in neural development. Neuron 2011, 71, 574-588. [CrossRef]

89. Singh, J.; Verma, R.; Raghav, R.; Sarkar, S.; Sood, M.; Jain, R. Brain-derived neurotrophic factor (BDNF) levels in first-episode schizophrenia and healthy controls: A comparative study. Asian J. Psychiatry 2020, 54, 102370. [CrossRef]

90. Rai, K.S.; Hattiangady, B.; Shetty, A.K. Enhanced production and dendritic growth of new dentate granule cells in the middle-aged hippocampus following intracerebroventricular FGF-2 infusions. Eur. J. Neurosci. 2007, 26, 1765-1779. [CrossRef]

91. Ren, L.; Wei, C.; Li, K.; Lu, Z. LncRNA MALAT1 up-regulates VEGF-A and ANGPT2 to promote angiogenesis in brain microvascular endothelial cells against oxygen-glucose deprivation via targetting miR-145. Biosci. Rep. 2019, 39. [CrossRef]

92. Zhou, Z.W.; Zheng, L.J.; Ren, X.; Li, A.P.; Zhou, W.S. LncRNA NEAT1 facilitates survival and angiogenesis in oxygen-glucose deprivation (OGD)-induced brain microvascular endothelial cells (BMECs) via targeting miR-377 and upregulating SIRT1, VEGFA, and BCL-XL. Brain Res. 2019, 1707, 90-98. [CrossRef] [PubMed]

93. Zhao, M.; Wang, J.; Xi, X.; Tan, N.; Zhang, L. SNHG12 Promotes Angiogenesis Following Ischemic Stroke via Regulating miR-150/VEGF Pathway. Neuroscience 2018, 390, 231-240. [CrossRef]

94. Dong, B.; Zhou, B.; Sun, Z.; Huang, S.; Han, L.; Nie, H.; Chen, G.; Liu, S.; Zhang, Y.; Bao, N.; et al. LncRNA-FENDRR mediates VEGFA to promote the apoptosis of brain microvascular endothelial cells via regulating miR-126 in mice with hypertensive intracerebral hemorrhage. Microcirculation 2018, 25, e12499. [CrossRef] [PubMed]

95. Huang, E.J.; Reichardt, L.F. Neurotrophins: Roles in neuronal development and function. Annu. Rev. Neurosci. 2001, 24, 677-736. [CrossRef] [PubMed] 
96. Park, H.; Poo, M.M. Neurotrophin regulation of neural circuit development and function. Nat. Rev. Neurosci. $2013,14,7-23$. [CrossRef] [PubMed]

97. Theoharides, T.C.; Athanassiou, M.; Panagiotidou, S.; Doyle, R. Dysregulated brain immunity and neurotrophin signaling in Rett syndrome and autism spectrum disorders. J. Neuroimmunol. 2015, 279, 33-38. [CrossRef]

98. Meng, W.D.; Sun, S.J.; Yang, J.; Chu, R.X.; Tu, W.; Liu, Q. Elevated Serum Brain-Derived Neurotrophic Factor (BDNF) but not BDNF Gene Val66Met Polymorphism Is Associated with Autism Spectrum Disorders. Mol. Neurobiol. 2017, 54, 1167-1172. [CrossRef]

99. de Azevedo Cardoso, T.; Mondin, T.C.; Wiener, C.D.; Marques, M.B.; Fucolo Bde, A.; Pinheiro, R.T.; de Souza, L.D.; da Silva, R.A.; Jansen, K.; Oses, J.P. Neurotrophic factors, clinical features and gender differences in depression. Neurochem. Res. 2014, 39, 1571-1578. [CrossRef]

100. Kotyuk, E.; Keszler, G.; Nemeth, N.; Ronai, Z.; Sasvari-Szekely, M.; Szekely, A. Glial cell line-derived neurotrophic factor (GDNF) as a novel candidate gene of anxiety. PLoS ONE 2013, 8, e80613. [CrossRef]

101. Walz, J.C.; Andreazza, A.C.; Frey, B.N.; Cacilhas, A.A.; Cereser, K.M.; Cunha, A.B.; Weyne, F.; Stertz, L.; Santin, A.; Goncalves, C.A.; et al. Serum neurotrophin-3 is increased during manic and depressive episodes in bipolar disorder. Neurosci. Lett. 2007, 415, 87-89. [CrossRef]

102. Allen, S.J.; Watson, J.J.; Shoemark, D.K.; Barua, N.U.; Patel, N.K. GDNF, NGF and BDNF as therapeutic options for neurodegeneration. Pharmacol. Ther. 2013, 138, 155-175. [CrossRef] [PubMed]

103. Bilgic, A.; Toker, A.; Isik, U.; Kilinc, I. Serum brain-derived neurotrophic factor, glial-derived neurotrophic factor, nerve growth factor, and neurotrophin-3 levels in children with attention-deficit/hyperactivity disorder. Eur. Child. Adolesc. Psychiatry 2017, 26, 355-363. [CrossRef] [PubMed]

104. Briggs, J.A.; Wolvetang, E.J.; Mattick, J.S.; Rinn, J.L.; Barry, G. Mechanisms of Long Non-coding RNAs in Mammalian Nervous System Development, Plasticity, Disease, and Evolution. Neuron 2015, 88, 861-877. [CrossRef] [PubMed]

105. Fatemi, R.P.; Velmeshev, D.; Faghihi, M.A. De-repressing LncRNA-Targeted Genes to Upregulate Gene Expression: Focus on Small Molecule Therapeutics. Molecular therapy. Nucleic Acids 2014, 3, e196. [CrossRef] [PubMed]

106. Choi, D.C.; Maguschak, K.A.; Ye, K.; Jang, S.W.; Myers, K.M.; Ressler, K.J. Prelimbic cortical BDNF is required for memory of learned fear but not extinction or innate fear. Proc. Natl. Acad. Sci. USA 2010, 107, 2675-2680. [CrossRef]

107. Lipovich, L.; Dachet, F.; Cai, J.; Bagla, S.; Balan, K.; Jia, H.; Loeb, J.A. Activity-dependent human brain coding/noncoding gene regulatory networks. Genetics 2012, 192, 1133-1148. [CrossRef]

108. Modarresi, F.; Faghihi, M.A.; Lopez-Toledano, M.A.; Fatemi, R.P.; Magistri, M.; Brothers, S.P.; van der Brug, M.P.; Wahlestedt, C. Inhibition of natural antisense transcripts in vivo results in gene-specific transcriptional upregulation. Nat. Biotechnol. 2012, 30, 453-459. [CrossRef]

109. Zhang, Y.; Yan, L.; Cao, Y.; Kong, G.; Lin, C. Long noncoding RNA BDNF-AS protects local anesthetic induced neurotoxicity in dorsal root ganglion neurons. Biomed. Pharmacother. 2016, 80, 207-212. [CrossRef]

110. Wang, H.; Chan, S.A.; Ogier, M.; Hellard, D.; Wang, Q.; Smith, C.; Katz, D.M. Dysregulation of brain-derived neurotrophic factor expression and neurosecretory function in Mecp2 null mice. J. Neurosci. Off. J. Soc. Neurosci. 2006, 26, 10911-10915. [CrossRef]

111. Rao, S.Q.; Hu, H.L.; Ye, N.; Shen, Y.; Xu, Q. Genetic variants in long non-coding RNA MIAT contribute to risk of paranoid schizophrenia in a Chinese Han population. Schizophr. Res. 2015, 166, 125-130. [CrossRef]

112. Sone, M.; Hayashi, T.; Tarui, H.; Agata, K.; Takeichi, M.; Nakagawa, S. The mRNA-like noncoding RNA Gomafu constitutes a novel nuclear domain in a subset of neurons. J. Cell Sci. 2007, 120, 2498-2506. [CrossRef] [PubMed]

113. Li, E.Y.; Zhao, P.J.; Jian, J.; Yin, B.Q.; Sun, Z.Y.; Xu, C.X.; Tang, Y.C.; Wu, H. LncRNA MIAT overexpression reduced neuron apoptosis in a neonatal rat model of hypoxic-ischemic injury through miR-211/GDNF. Cell Cycle 2019, 18, 156-166. [CrossRef] [PubMed]

114. Jiang, Q.; Shan, K.; Qun-Wang, X.; Zhou, R.M.; Yang, H.; Liu, C.; Li, Y.J.; Yao, J.; Li, X.M.; Shen, Y.; et al. Long non-coding RNA-MIAT promotes neurovascular remodeling in the eye and brain. Oncotarget 2016, 7, 49688-49698. [CrossRef]

115. Albertson, D.N.; Schmidt, C.J.; Kapatos, G.; Bannon, M.J. Distinctive profiles of gene expression in the human nucleus accumbens associated with cocaine and heroin abuse. Neuropsychopharmacology 2006, 31, 2304-2312. [CrossRef] [PubMed]

116. Barry, G.; Briggs, J.A.; Vanichkina, D.P.; Poth, E.M.; Beveridge, N.J.; Ratnu, V.S.; Nayler, S.P.; Nones, K.; Hu, J.; Bredy, T.W.; et al. The long non-coding RNA Gomafu is acutely regulated in response to neuronal activation and involved in schizophreniaassociated alternative splicing. Mol. Psychiatry 2014, 19, 486-494. [CrossRef]

117. Ip, J.Y.; Sone, M.; Nashiki, C.; Pan, Q.; Kitaichi, K.; Yanaka, K.; Abe, T.; Takao, K.; Miyakawa, T.; Blencowe, B.J.; et al. Gomafu IncRNA knockout mice exhibit mild hyperactivity with enhanced responsiveness to the psychostimulant methamphetamine. Sci. Rep. 2016, 6, 27204. [CrossRef]

118. Hodge, R.G.; Ridley, A.J. Regulating Rho GTPases and their regulators. Nat. Rev. Mol. Cell Biol. 2016, 17, 496-510. [CrossRef]

119. Govek, E.E.; Newey, S.E.; Van Aelst, L. The role of the Rho GTPases in neuronal development. Genes Dev. 2005, 19, 1-49. [CrossRef]

120. Zamboni, V.; Jones, R.; Umbach, A.; Ammoni, A.; Passafaro, M.; Hirsch, E.; Merlo, G.R. Rho GTPases in Intellectual Disability: From Genetics to Therapeutic Opportunities. Int. J. Mol. Sci. 2018, 19, 1821. [CrossRef]

121. Seger, R.; Krebs, E.G. The MAPK signaling cascade. FASEB J. 1995, 9, 726-735. [CrossRef] 
122. Cargnello, M.; Roux, P.P. Activation and function of the MAPKs and their substrates, the MAPK-activated protein kinases. Microbiol. Mol. Biol. Rev. 2011, 75, 50-83. [CrossRef] [PubMed]

123. Keshet, Y.; Seger, R. The MAP kinase signaling cascades: A system of hundreds of components regulates a diverse array of physiological functions. Methods Mol. Biol. 2010, 661, 3-38. [CrossRef] [PubMed]

124. Miller, F.D.; Gauthier, A.S. Timing is everything: Making neurons versus glia in the developing cortex. Neuron 2007, 54, 357-369. [CrossRef] [PubMed]

125. Sweatt, J.D. Mitogen-activated protein kinases in synaptic plasticity and memory. Curr. Opin. Neurobiol. 2004, 14, 311-317. [CrossRef] [PubMed]

126. Albert-Gasco, H.; Ros-Bernal, F.; Castillo-Gomez, E.; Olucha-Bordonau, F.E. MAP/ERK Signaling in Developing Cognitive and Emotional Function and Its Effect on Pathological and Neurodegenerative Processes. Int. J. Mol. Sci. 2020, 21, 4471. [CrossRef] [PubMed]

127. Vithayathil, J.; Pucilowska, J.; Landreth, G.E. ERK/MAPK signaling and autism spectrum disorders. Prog. Brain Res. 2018, 241, 63-112. [CrossRef]

128. Subramanian, M.; Timmerman, C.K.; Schwartz, J.L.; Pham, D.L.; Meffert, M.K. Characterizing autism spectrum disorders by key biochemical pathways. Front. Neurosci. 2015, 9, 313. [CrossRef]

129. Yufune, S.; Satoh, Y.; Takamatsu, I.; Ohta, H.; Kobayashi, Y.; Takaenoki, Y.; Pages, G.; Pouyssegur, J.; Endo, S.; Kazama, T. Transient Blockade of ERK Phosphorylation in the Critical Period Causes Autistic Phenotypes as an Adult in Mice. Sci. Rep. 2015, 5, 10252. [CrossRef]

130. Paoletti, P.; Neyton, J. NMDA receptor subunits: Function and pharmacology. Curr. Opin. Pharmacol. 2007, 7, 39-47. [CrossRef]

131. Kohr, G. NMDA receptor function: Subunit composition versus spatial distribution. Cell Tissue Res. 2006, 326, 439-446. [CrossRef]

132. Wu, Q.J.; Tymianski, M. Targeting NMDA receptors in stroke: New hope in neuroprotection. Mol. Brain 2018, 11, 15. [CrossRef] [PubMed]

133. Burnashev, N.; Szepetowski, P. NMDA receptor subunit mutations in neurodevelopmental disorders. Curr. Opin. Pharmacol. 2015, 20, 73-82. [CrossRef] [PubMed]

134. Mota, S.I.; Ferreira, I.L.; Rego, A.C. Dysfunctional synapse in Alzheimer's disease-A focus on NMDA receptors. Neuropharmacology 2014, 76, 16-26. [CrossRef] [PubMed]

135. Li, D.; Zhang, J.; Wang, M.; Li, X.; Gong, H.; Tang, H.; Chen, L.; Wan, L.; Liu, Q. Activity dependent LoNA regulates translation by coordinating rRNA transcription and methylation. Nat. Commun. 2018, 9, 1726. [CrossRef] [PubMed]

136. Gamache, T.R.; Araki, Y.; Huganir, R.L. Twenty Years of SynGAP Research: From Synapses to Cognition. J. Neurosci. 2020, 40, 1596-1605. [CrossRef] [PubMed]

137. Velmeshev, D.; Magistri, M.; Faghihi, M.A. Expression of non-protein-coding antisense RNAs in genomic regions related to autism spectrum disorders. Mol. Autism 2013, 4, 32. [CrossRef] [PubMed]

138. Hamdan, F.F.; Gauthier, J.; Spiegelman, D.; Noreau, A.; Yang, Y.; Pellerin, S.; Dobrzeniecka, S.; Cote, M.; Perreau-Linck, E.; Carmant, L.; et al. Mutations in SYNGAP1 in autosomal nonsyndromic mental retardation. N. Engl. J. Med. 2009, 360, 599-605. [CrossRef]

139. Kilinc, M.; Creson, T.; Rojas, C.; Aceti, M.; Ellegood, J.; Vaissiere, T.; Lerch, J.P.; Rumbaugh, G. Species-conserved SYNGAP1 phenotypes associated with neurodevelopmental disorders. Mol. Cell. Neurosci. 2018, 91, 140-150. [CrossRef]

140. Berryer, M.H.; Hamdan, F.F.; Klitten, L.L.; Moller, R.S.; Carmant, L.; Schwartzentruber, J.; Patry, L.; Dobrzeniecka, S.; Rochefort, D.; Neugnot-Cerioli, M.; et al. Mutations in SYNGAP1 cause intellectual disability, autism, and a specific form of epilepsy by inducing haploinsufficiency. Hum. Mutat. 2013, 34, 385-394. [CrossRef]

141. Liyanage, V.R.B. Role of RNA Methylation and Non-Coding RNAs in Pathobiology of Autism Spectrum Disorders. Biomed. Sci. 2016, 2, 24-33. [CrossRef]

142. Ji, P.; Diederichs, S.; Wang, W.; Boing, S.; Metzger, R.; Schneider, P.M.; Tidow, N.; Brandt, B.; Buerger, H.; Bulk, E.; et al. MALAT-1, a novel noncoding RNA, and thymosin beta4 predict metastasis and survival in early-stage non-small cell lung cancer. Oncogene 2003, 22, 8031-8041. [CrossRef] [PubMed]

143. Tian, X.; Xu, G. Clinical value of lncRNA MALAT1 as a prognostic marker in human cancer: Systematic review and meta-analysis. BMJ Open 2015, 5, e008653. [CrossRef] [PubMed]

144. Li, Z.; Xu, C.; Ding, B.; Gao, M.; Wei, X.; Ji, N. Long non-coding RNA MALAT1 promotes proliferation and suppresses apoptosis of glioma cells through derepressing Rap1B by sponging miR-101. J. Neuro Oncol. 2017, 134, 19-28. [CrossRef] [PubMed]

145. Chen, Y.; Huang, W.; Sun, W.; Zheng, B.; Wang, C.; Luo, Z.; Wang, J.; Yan, W. LncRNA MALAT1 Promotes Cancer Metastasis in Osteosarcoma via Activation of the PI3K-Akt Signaling Pathway. Cell. Physiol. Biochem. 2018, 51, 1313-1326. [CrossRef] [PubMed]

146. Ng, S.Y.; Lin, L.; Soh, B.S.; Stanton, L.W. Long noncoding RNAs in development and disease of the central nervous system. Trends Genet. 2013, 29, 461-468. [CrossRef]

147. Bernard, D.; Prasanth, K.V.; Tripathi, V.; Colasse, S.; Nakamura, T.; Xuan, Z.; Zhang, M.Q.; Sedel, F.; Jourdren, L.; Coulpier, F.; et al. A long nuclear-retained non-coding RNA regulates synaptogenesis by modulating gene expression. EMBO J. 2010, 29, $3082-3093$. [CrossRef]

148. Li, D.; Zhang, J.; Li, X.; Chen, Y.; Yu, F.; Liu, Q. Insights into lncRNAs in Alzheimer's disease mechanisms. RNA Biol. 2020, 10, 1-11. [CrossRef] 
149. Chen, L.; Feng, P.; Zhu, X.; He, S.; Duan, J.; Zhou, D. Long non-coding RNA Malat1 promotes neurite outgrowth through activation of ERK/MAPK signalling pathway in N2a cells. J. Cell. Mol. Med. 2016, 20, 2102-2110. [CrossRef]

150. Shi, Y.L.; Wang, Q.; Wei, J.C. Influence of lncRNA-MALAT1 on neuronal apoptosis in rats with cerebral infarction through regulating the ERK/MAPK signaling pathway. Eur. Rev. Med. Pharmacol. Sci. 2019, 23, 8039-8048. [CrossRef]

151. Marin-Bejar, O.; Marchese, F.P.; Athie, A.; Sanchez, Y.; Gonzalez, J.; Segura, V.; Huang, L.; Moreno, I.; Navarro, A.; Monzo, M.; et al. Pint lincRNA connects the p53 pathway with epigenetic silencing by the Polycomb repressive complex 2. Genome Biol. 2013, 14, R104. [CrossRef]

152. Bluthgen, N.; van Bentum, M.; Merz, B.; Kuhl, D.; Hermey, G. Profiling the MAPK/ERK dependent and independent activity regulated transcriptional programs in the murine hippocampus in vivo. Sci. Rep. 2017, 7, 45101. [CrossRef] [PubMed]

153. An, H.; Williams, N.G.; Shelkovnikova, T.A. NEAT1 and paraspeckles in neurodegenerative diseases: A missing lnc found? Non Coding RNA Res. 2018, 3, 243-252. [CrossRef] [PubMed]

154. Sasaki, Y.T.; Ideue, T.; Sano, M.; Mituyama, T.; Hirose, T. MENepsilon/beta noncoding RNAs are essential for structural integrity of nuclear paraspeckles. Proc. Natl. Acad. Sci. USA 2009, 106, 2525-2530. [CrossRef] [PubMed]

155. Huang, Z.; Zhao, J.; Wang, W.; Zhou, J.; Zhang, J. Depletion of LncRNA NEAT1 Rescues Mitochondrial Dysfunction Through NEDD4L-Dependent PINK1 Degradation in Animal Models of Alzheimer's Disease. Front. Cell. Neurosci. 2020, 14, 28. [CrossRef]

156. Klec, C.; Prinz, F.; Pichler, M. Involvement of the long noncoding RNA NEAT1 in carcinogenesis. Mol. Oncol. 2019, 13, 46-60. [CrossRef]

157. Prinz, F.; Kapeller, A.; Pichler, M.; Klec, C. The Implications of the Long Non-Coding RNA NEAT1 in Non-Cancerous Diseases. Int. J. Mol. Sci. 2019, 20, 627. [CrossRef]

158. Melland, H.; Carr, E.M.; Gordon, S.L. Disorders of synaptic vesicle fusion machinery. J. Neurochem. 2020. [CrossRef]

159. Owens, D.F.; Kriegstein, A.R. Developmental neurotransmitters? Neuron 2002, 36, 989-991. [CrossRef]

160. Elbert, A.; Bérubé, N.G. Chromatin Structure and Intellectual Disability Syndromes. In Developmental Disabilities-Molecules Involved, Diagnosis, and Clinical Care; Salehi, A., Ed.; IntechOpen: London, UK, 2013. [CrossRef]

161. Broek, J.A.C.; Lin, Z.; de Gruiter, H.M.; van ‘t Spijker, H.; Haasdijk, E.D.; Cox, D.; Ozcan, S.; van Cappellen, G.W.A.; Houtsmuller, A.B.; Willemsen, R.; et al. Synaptic vesicle dynamic changes in a model of fragile X. Mol. Autism 2016, 7, 17. [CrossRef]

162. Salpietro, V.; Malintan, N.T.; Llano-Rivas, I.; Spaeth, C.G.; Efthymiou, S.; Striano, P.; Vandrovcova, J.; Cutrupi, M.C.; Chimenz, R.; David, E.; et al. Mutations in the Neuronal Vesicular SNARE VAMP2 Affect Synaptic Membrane Fusion and Impair Human Neurodevelopment. Am. J. Hum. Genet. 2019, 104, 721-730. [CrossRef]

163. Chen, Y.A.; Scales, S.J.; Patel, S.M.; Doung, Y.C.; Scheller, R.H. SNARE complex formation is triggered by Ca2+ and drives membrane fusion. Cell 1999, 97, 165-174. [CrossRef]

164. Elfving, B.; Muller, H.K.; Oliveras, I.; Osterbog, T.B.; Rio-Alamos, C.; Sanchez-Gonzalez, A.; Tobena, A.; Fernandez-Teruel, A.; Aznar, S. Differential expression of synaptic markers regulated during neurodevelopment in a rat model of schizophrenia-like behavior. Prog. Neuro Psychopharmacol. Biol. Psychiatry 2019, 95, 109669. [CrossRef] [PubMed]

165. Wang, C.; Yang, B.; Fang, D.; Zeng, H.; Chen, X.; Peng, G.; Cheng, Q.; Liang, G. The impact of SNAP25 on brain functional connectivity density and working memory in ADHD. Biol. Psychol. 2018, 138, 35-40. [CrossRef]

166. Mustafin, R.N.; Enikeeva, R.F.; Malykh, S.B.; Valinurov, R.G.; Khusnutdinova, E.K. Genetics and epigenetics of attention deficit hyperactivity disorder. Zhurnal Nevrologii i Psikhiatrii imeni SS Korsakova 2018, 118, 106-110. [CrossRef] [PubMed]

167. Hawi, Z.; Cummins, T.D.; Tong, J.; Johnson, B.; Lau, R.; Samarrai, W.; Bellgrove, M.A. The molecular genetic architecture of attention deficit hyperactivity disorder. Mol. Psychiatry 2015, 20, 289-297. [CrossRef] [PubMed]

168. Keihani, S.; Kluever, V.; Mandad, S.; Bansal, V.; Rahman, R.; Fritsch, E.; Gomes, L.C.; Gartner, A.; Kugler, S.; Urlaub, H.; et al. The long noncoding RNA neuroLNC regulates presynaptic activity by interacting with the neurodegeneration-associated protein TDP-43. Sci. Adv. 2019, 5, eaay2670. [CrossRef]

169. Ling, S.C. Synaptic Paths to Neurodegeneration: The Emerging Role of TDP-43 and FUS in Synaptic Functions. Neural Plast. 2018, 2018, 8413496. [CrossRef]

170. Liu, G.; Coyne, A.N.; Pei, F.; Vaughan, S.; Chaung, M.; Zarnescu, D.C.; Buchan, J.R. Endocytosis regulates TDP-43 toxicity and turnover. Nat. Commun. 2017, 8, 2092. [CrossRef]

171. Ling, S.C.; Polymenidou, M.; Cleveland, D.W. Converging mechanisms in ALS and FTD: Disrupted RNA and protein homeostasis. Neuron 2013, 79, 416-438. [CrossRef]

172. Burk, K.; Pasterkamp, R.J. Disrupted neuronal trafficking in amyotrophic lateral sclerosis. Acta Neuropathol. 2019, $137,859-877$. [CrossRef]

173. Schwenk, B.M.; Hartmann, H.; Serdaroglu, A.; Schludi, M.H.; Hornburg, D.; Meissner, F.; Orozco, D.; Colombo, A.; Tahirovic, S.; Michaelsen, M.; et al. TDP-43 loss of function inhibits endosomal trafficking and alters trophic signaling in neurons. EMBO J. 2016, 35, 2350-2370. [CrossRef] [PubMed]

174. Long, Y.; Wang, X.; Youmans, D.T.; Cech, T.R. How do lncRNAs regulate transcription? Sci. Adv. 2017, 3, eaao2110. [CrossRef] [PubMed]

175. Tsai, M.C.; Manor, O.; Wan, Y.; Mosammaparast, N.; Wang, J.K.; Lan, F.; Shi, Y.; Segal, E.; Chang, H.Y. Long noncoding RNA as modular scaffold of histone modification complexes. Science 2010, 329, 689-693. [CrossRef] [PubMed] 
176. Chalei, V.; Sansom, S.N.; Kong, L.; Lee, S.; Montiel, J.F.; Vance, K.W.; Ponting, C.P. The long non-coding RNA Dali is an epigenetic regulator of neural differentiation. eLife 2014, 3, e04530. [CrossRef] [PubMed]

177. Nakai, S.; Sugitani, Y.; Sato, H.; Ito, S.; Miura, Y.; Ogawa, M.; Nishi, M.; Jishage, K.; Minowa, O.; Noda, T. Crucial roles of Brn1 in distal tubule formation and function in mouse kidney. Development 2003, 130, 4751-4759. [CrossRef] [PubMed]

178. Gu, Y.; Xiang, B.; Zhu, L.; Ma, X.; Chen, X.; Cai, T. Three intellectual disability-associated de novo mutations in MECP2 identified by trio-WES analysis. BMC Med. Genet. 2020, 21, 99. [CrossRef]

179. Gonzales, M.L.; LaSalle, J.M. The role of MeCP2 in brain development and neurodevelopmental disorders. Curr. Psychiatry Rep. 2010, 12, 127-134. [CrossRef]

180. Amir, R.E.; Van den Veyver, I.B.; Wan, M.; Tran, C.Q.; Francke, U.; Zoghbi, H.Y. Rett syndrome is caused by mutations in X-linked MECP2, encoding methyl-CpG-binding protein 2. Nat. Genet. 1999, 23, 185-188. [CrossRef]

181. Maxwell, S.S.; Pelka, G.J.; Tam, P.P.; El-Osta, A. Chromatin context and ncRNA highlight targets of MeCP2 in brain. RNA Biol. 2013, 10, 1741-1757. [CrossRef]

182. Keppetipola, N.; Sharma, S.; Li, Q.; Black, D.L. Neuronal regulation of pre-mRNA splicing by polypyrimidine tract binding proteins, PTBP1 and PTBP2. Crit. Rev. Biochem. Mol. Biol. 2012, 47, 360-378. [CrossRef]

183. Lin, N.; Chang, K.Y.; Li, Z.; Gates, K.; Rana, Z.A.; Dang, J.; Zhang, D.; Han, T.; Yang, C.S.; Cunningham, T.J.; et al. An evolutionarily conserved long noncoding RNA TUNA controls pluripotency and neural lineage commitment. Mol. Cell 2014, 53, 1005-1019. [CrossRef] [PubMed]

184. Cuevas-Diaz Duran, R.; Wei, H.; Kim, D.H.; Wu, J.Q. Invited Review: Long non-coding RNAs: Important regulators in the development, function and disorders of the central nervous system. Neuropathol. Appl. Neurobiol. 2019, 45, 538-556. [CrossRef] [PubMed]

185. Aprea, J.; Prenninger, S.; Dori, M.; Ghosh, T.; Monasor, L.S.; Wessendorf, E.; Zocher, S.; Massalini, S.; Alexopoulou, D.; Lesche, M.; et al. Transcriptome sequencing during mouse brain development identifies long non-coding RNAs functionally involved in neurogenic commitment. EMBO J. 2013, 32, 3145-3160. [CrossRef] [PubMed]

186. Ray, M.K.; Wiskow, O.; King, M.J.; Ismail, N.; Ergun, A.; Wang, Y.; Plys, A.J.; Davis, C.P.; Kathrein, K.; Sadreyev, R.; et al. CAT7 and cat7l Long Non-coding RNAs Tune Polycomb Repressive Complex 1 Function during Human and Zebrafish Development. J. Biol. Chem. 2016, 291, 19558-19572. [CrossRef] [PubMed] 